The University of Southern Mississippi

The Aquila Digital Community

Faculty Publications

8-2015

\title{
A Multiple Endpoint Analysis of the Effects of Chronic Exposure to Sediment Contaminated with Deepwater Horizon Oil On Juvenile Southern Flounder and Their Associated Microbiomes
}

\author{
Nancy J. Brown-Peterson \\ University of Southern Mississippi, nancy.brown-peterson@usm.edu \\ Michelle Krasnec \\ Abt Associates \\ Ryan Takeshita \\ Abt Associates \\ Caitlin N. Ryan \\ Texas Tech University \\ Kimberly J. Griffitt \\ University of Southern Mississippi
}

See next page for additional authors

Follow this and additional works at: https://aquila.usm.edu/fac_pubs

\section{Recommended Citation}

Brown-Peterson, N. J., Krasnec, M., Takeshita, R., Ryan, C. N., Griffitt, K. J., Lay, C., Mayer, G. D., Bayha, K. M., Hawkins, W. E., Morris, J., Griffitt, R. J. (2015). A Multiple Endpoint Analysis of the Effects of Chronic Exposure to Sediment Contaminated with Deepwater Horizon Oil On Juvenile Southern Flounder and Their Associated Microbiomes. Aquatic Toxicology, 165, 197-209.

Available at: https://aquila.usm.edu/fac_pubs/15692

This Article is brought to you for free and open access by The Aquila Digital Community. It has been accepted for inclusion in Faculty Publications by an authorized administrator of The Aquila Digital Community. For more information, please contact Joshua.Cromwell@usm.edu. 


\section{Authors}

Nancy J. Brown-Peterson, Michelle Krasnec, Ryan Takeshita, Caitlin N. Ryan, Kimberly J. Griffitt, Claire Lay, Gregory D. Mayer, Keith M. Bayha, William E. Hawkins, Jeffrey Morris, and Robert J. Griffitt 
A multiple endpoint analysis of the effects of chronic exposure to sediment contaminated with Deepwater Horizon oil on juvenile Southern flounder and their associated microbiomes.

Nancy J. Brown-Peterson ${ }^{\mathrm{a}}$, Michelle Krasnec ${ }^{\mathrm{b}}$, Ryan Takeshita ${ }^{2}$, Caitlin N. Ryan ${ }^{\mathrm{c}}$, Kimberly J. Griffitt $^{\mathrm{a}}$, Claire Lay ${ }^{\mathrm{b}}$, Gregory D. Mayer ${ }^{\mathrm{c}}$, Keith M. Bayha ${ }^{\mathrm{a}}$, William E. Hawkins ${ }^{\mathrm{a}}$, Jeffrey Morris $^{\mathrm{b}}$ and Robert J. Griffitt ${ }^{\mathrm{a}, 1}$

${ }^{a}$ Department of Coastal Sciences, The University of Southern Mississippi, 703 East Beach Dr., Ocean Springs, MS 39564 (nancy.brown-peterson@usm.edu; kim.griffitt@gmail.com;

kmbayha@gmail.com; william.hawkins@usm.edu; joe.griffitt@usm.edu); ${ }^{b}$ Abt Associates, 1881

Ninth Street, Suite 201, Boulder, Colorado 80302 (MKrasnec@ @ stratusconsulting.com;

RTakeshita@stratusconsulting.com; claymsc@stratusconsulting.com;

JMorrisMSCanyon252@ @ stratusconsulting.com); ${ }^{\mathrm{C}}$ The Institute of Environmental and Human Health, Department of Environmental Toxicology, Texas Tech University, Box 41163, Lubbock, TX 79409 (Caitlin.ryan@ttu.edu; greg.mayer@ttu.edu)

${ }^{1}$ Corresponding author: Robert J. Griffitt, Department of Coastal Sciences, The University of Southern Mississippi, 703 East Beach Drive, Ocean Springs, MS 39564; joe.griffitt@ usm.edu; 228-872-4294

Short Title: Oiled sediments impact juvenile flounder 


\section{Abstract}

Exposure to oiled sediments can negatively impact the health of fish species. Here, we examine the effects of chronic exposure of juvenile southern flounder, Paralichthys lethostigma, to a sediment-oil mixture. Oil:sediment mixtures are persistent over time and can become bioavailable following sediment perturbation or resuspension. Juvenile flounder were exposed for 32 days under controlled laboratory conditions to five concentrations of naturally weathered Macondo MC252 oil mixed into uncontaminated, field-collected sediments. The percent composition of individual polycyclic aromatic hydrocarbons (PAHs) of the weathered oil did not change after mixing with the sediment. Spiked exposure sediments contained 0.04-395 mg/kg tPAH50 (sum of 50 individual PAH concentration measurements). Mortality increased with both exposure duration and concentration of sediment-associated PAHs, and flounder exposed to concentrations above $8 \mathrm{mg} / \mathrm{kg}$ tPAH50 showed significantly reduced growth over the course of the experiment. Evident histopathologic changes were observed in liver and gill tissues of fish exposed to more than $8 \mathrm{mg} / \mathrm{kg}$ tPAH50. All fish at these concentrations showed hepatic intravascular congestion, macrovesicular hepatic vacoulation, telangiectasia of secondary lamellae, and lamellar epithelial proliferation in gill tissues. Dose-dependent upregulation of CYP1A expression in liver tissues was observed. Taxonomic analysis of gill and intestinal commensal bacterial assemblages showed that exposure to oiled sediments led to distinct shifts in commensal bacterial population structures. These data show that chronic exposure to environmentally-relevant concentrations of oiled sediments produces adverse effects in flounder at multiple biological levels.

Key Words: PAH, ecotoxicology, histopathology, gene expression, microbiome, Paralichthys 


\subsection{Introduction}

The BP Deepwater Horizon (DWH) accident released an estimated 4.9 million barrels of Louisiana sweet crude oil into the northern Gulf of Mexico (GOM) over an 87 day period between 20 April and 15 July 2010. While some of this oil was recovered and removed, much was evident as surface slicks that washed onshore into marshes and onto beaches of Louisiana, Mississippi and Alabama (Michel et al., 2013) throughout the duration of the spill; additionally, an unknown, but certainly large amount settled into the sediments of the northern GOM (Wang and Roberts, 2013). While measured PAH concentrations of surface waters showed negligible oil contamination one year after the spill (Allan et al., 2012), crude oil remains in sediments for a much longer time and exhibits slower weathering (Liu et al., 2012). Thus, benthic organisms may be susceptible to impacts from the DWH oil several years after the spill and associated clean-up, particularly as oiled sediments are mixed or disturbed by storms, currents and dredging activities. For instance, species number, density and biomass of macrobenthic communities remained depressed two years after the 2007 Hebei Spirit oil spill in Korea (Hong et al., 2014), and pink salmon embryos spawned in sediments contaminated by the Exxon Valdez spill exhibited elevated mortality five years after the spill and associated clean-up (Ballachey et al., 2014).

The effects of the DWH oil spill have impacted flora and fauna at multiple biological levels, including marine mammals (Schwacke et al., 2013; Wise and and J. P. Wise, 2014), fishes (Brewton et al., 2013; Brown-Peterson, 2014; Dubansky et al., 2013; Echols et al., 2015), invertebrates (Carmichael et al., 2012; Echols et al., 2015; Goodbody-Gringley et al., 2013; McCall and Pennings, 2012), and gelatinous zooplankton (Almeda et al., 2013) to microbial food webs (Ortmann et al., 2012) and salt marsh vegetation (Silliman et al., 2012). Many of these 
studies have focused on exposure to oil in the water column, either through collections of specimens directly from the environment or in experimental exposures to a water accommodated fraction (WAF) of oil. Exposure of embryos of Gulf killifish (Fundulus grandis) and zebrafish (Danio rerio) to oiled sediments resulted in reduced hatch and developmental anomalies (Dubansky et al., 2013; Raimondo et al., 2014), suggesting oiled sediments can significantly impact young fishes. However, there is little information to date on the impact of oiled sediments from the DWH spill on juvenile or adult benthic fish species. Additionally, while many studies have examined physiological or molecular impacts of DWH oil exposure on fishes (Brette et al., 2014; Crowe et al., 2014; Dubansky et al., 2013; Incardona et al., 2014; Pilcher et al., 2014; Whitehead et al., 2011), relatively few reports combine whole animal and molecular measurements from the same individuals (e.g. (Brewton et al., 2013)) to allow an overall assessment of the impacts of DWH oil on multiple aspects of fish condition.

Here, we report the effects of sediment mixed with naturally weathered DWH oil on juvenile southern flounder (Paralichthys lethostigma), a common ecologically and recreationally important benthic fish in the northern GOM. We hypothesized that oiled sediments would impact juvenile flounder at a variety of levels, including organismal (survival, growth), tissue (histopathology of liver and gill), molecular (gene expression), and holobiotic (gut and gill commensal microbiome) endpoints. By investigating effects at multiple biological levels, we are able to obtain a more complete and thorough understanding of the mechanisms by which oiled sediments affect benthic organisms.

\subsection{Materials and Methods}

\subsection{Oil Samples and Sediment Preparation}


Reference, non-oiled sediments were collected from Alabama marshes $\left(30^{\circ} 22^{\prime} 45.72 " \mathrm{~N}\right.$;

$88^{\circ} 18^{\prime} 24.40 " \mathrm{~W}$ ) on 27 Nov 2012 and frozen for transport to the laboratory. Weathered Louisiana MC252 crude oil samples (BP code 00003277) used in this experiment (hereafter referred to as Slick B) were collected under chain of custody from the northern GOM on 19 July 2010 during DWH response efforts. Sediments were weighed, thawed and mixed with varying amounts of Slick B oil for 30 min using a KitchenAid stand mixer on medium speed (amounts and concentrations reported in Table S1) to achieve targeted concentrations of sediment-associated PAHs. The mixed sediments were distributed into individual numbered cages $(10 \mathrm{~cm}$ glass petri dish with a $20 \mathrm{~cm}$ column of $2 \mathrm{~mm}$ nylon mesh; $75 \mathrm{~g}$ sediment/cage) and placed into $20 \mathrm{~L}$ treatment aquaria. The sediments were allowed to settle overnight following addition of 10L of seawater to each aquarium. The exposures were performed in quadruplicate with 8 individual cages per replicate tank (32 total fish per treatment level), with a control and five concentrations of Slick B oil (measured concentrations of 0, 0.7, 8, 54, 127, $395 \mathrm{mg}$ tPAH50/kg sediment). These concentrations are consistent with measured oil range organics from sediments of estuarine areas collected from June through October 2010 (30 - 200 mg/kg; (Floyd et al., 2012), and thus represent environmentally realistic exposure levels.

\subsection{Fish Exposures}

Post metamorphosis juvenile southern flounder (53 days post hatch, 7-18 mm SL, spawned and raised in captive, uncontaminated conditions) were obtained from the University of Texas Marine Science Institute mariculture facility. Upon receipt, flounder were acclimated to culture conditions (salinity $15 \mathrm{psu}, 22^{\circ} \mathrm{C}, \mathrm{pH} 8.0,12 \mathrm{~L}: 12 \mathrm{D}$ photoperiod) over a period of 25 days and maintained in these conditions for an additional 5 days prior to experimentation. Fish were fed 
commercial pellet food (Ottohime B2) twice daily during acclimation and exposure. At test initiation, fish ranged from 18-35 mm SL.

Clean artificial seawater prepared from Fritz Super Salt, diluted to 15 psu salinity, filtered and UV-sterilized was used in a flow-through experimental system (Manning et al., 1999). System cycling ensured addition of $500 \mathrm{ml}$ of fresh seawater into each treatment aquarium every $15 \mathrm{~min}$, resulting in daily water renewal of $48 \mathrm{~L} /$ aquaria. Thus, this experimental design consisted of contaminated sediments with uncontaminated water flowing into each tank. Treatment aquaria were maintained at $22 \pm 2^{\circ} \mathrm{C}$ and a $12 \mathrm{~L}: 12 \mathrm{D}$ photoperiod throughout the experiment. Compressed oxygen was bubbled into each aquarium such that D.O. was maintained at $\geq 4 \mathrm{mg} / \mathrm{L}$.

At test initiation, flounder were individually weighed $(0.1 \mathrm{mg})$, measured ( $\mathrm{mm}$ standard length (SL)), and added to 1 cage/ aquarium in random order in 8 rounds of additions. Aquaria were covered with foil lids to prevent evaporation and cross-tank contamination. The flounder were inspected daily for the 32-d duration of the experiment and dead fish were removed and recorded. We digitally recorded video footage of each flounder twice weekly for additional growth measurements before the end of the experiment. A 25-mm Teflon coated stir bar was placed into each cage and used as a size reference to facilitate SL measurements of each fish using the digital imagery. Still images were captured from videos in which both the entire fish and the entire inert bar were present in the frame. Both the inert bar and the fish were measured using digital measurement estimation in Microsoft Paint. Water quality (temperature, salinity, pH, D.O., and ammonia) was measured daily in each aquarium. At test termination, flounder were euthanized in MS-222, weighed and measured. Liver, intestine, and top and bottom gill tissues from 4 fish/replicate aquarium were removed and individually stored in $1 \mathrm{~mL}$ RNALater (Ambion) for subsequent analyses. Livers were weighed (LW, mg) following storage in 
RNALater. The tails were removed from 4 fish/replicate aquarium and the anterior carcass was preserved in $10 \%$ neutral buffered formalin for histopathologic analyses.

\subsection{Analysis of Sediment and Water Samples}

Grain size was analyzed from sediments at the time of initial collection following standard ASTM methodology (ASTM, 2007). Total Organic Carbon (TOC, \%) was analyzed in control sediments at experiment initiation and termination following EPA method 9060A (http://www.epa.gov/epawaste/hazard/testmethods/sw846/online/index.htm); TOC was not analyzed in the oil-mixed sediments to avoid interference from the signature of the oil added intentionally. Composite sediments from each treatment and the control and were analyzed for a suite of $50 \mathrm{PAH}$ analytes (tPAH50) at experiment initiation and termination by gas chromatography with low resolution mass spectrometry using selected ion monitoring (GC/MSSIM) . The analytical procedure is based on EPA Method 8270D (Kimbrough et al., 2006; Murphy and Morrison, 2007). The PAH composition of the Slick B oil was analyzed following the same procedures. Filtered and unfiltered composite water samples were collected from each treatment at experiment initiation and at days 2, 4, 6, 8, 12, 19, 26, and 32 of exposure and analyzed for tPAH50 concentration following the same procedure referenced above. All chemical analyses were performed by ALS Environmental (Kelso, WA). Additionally, duplicate unfiltered water samples from each replicate aquarium were collected at the same 9 time points, mixed with an equal volume of absolute ethanol, centrifuged, and scanned at $380 \mathrm{~nm}$ emission and $270 \mathrm{~nm}$ excitation following (Greer et al., 2012) to assess inter-replicate variability and changes in PAH in overlying water in treatments over the course of the experiment.

\subsection{Histopathologic Procedures}


Whole, preserved flounder were decalcified, processed and embedded in paraffin following standard histological techniques; tissue was sectioned at $4 \mu \mathrm{m}$ at two levels and stained with hematoxylin and eosin. Three separate readers independently evaluated liver, gill, heart and kidney tissues at both levels for all specimens and diagnoses were based on both levels combined; identity of treatments was blinded for initial readings. Histopathologic observations of top and bottom gills were combined for the analyses; while the bottom gill is in more direct contact with the contaminated sediments, water is pumped directly through both top and bottom gills, likely resulting in little difference in exposure. Histopathologic conditions in all evaluated tissues were rated as 0 (condition not observed) or 1 (condition observed), and the percentage of fish in each treatment presenting an observed histopathologic anomaly was calculated and presented as consensus scores. Photographs of all liver and gill tissue were taken of each specimen for quantification of treatment-related effects. The percentage of liver tissue exhibiting intravascular congestion and macro- or micro-vesicular vacuolation was quantified in three randomly chosen photos/specimen using the grid plug-in for Image $\mathbf{J}$ analysis based on methodology described by Tomkiewicz et al. (Tomkiewicz et al., 2011). The total number of gill lamellae were counted in three randomly chosen photos/specimen; the number of those lamellae exhibiting epithelial proliferation (defined as proliferation on the lamellae at the base of the secondary lamellae) and the number containing secondary lamellae with telangiectasis were counted using Image J. Finally, a rank of 0-4 (none, $<25 \%, 25-50 \%, 51-75 \%,>75 \%$ ) was assigned for each lamellae based on the percentage of secondary lamellae per lamellae that exhibited telangiectasis, and a mean rank of telangiectasis was calculated for each specimen.

\subsection{Gene Expression}


Expression of Cytochrome p450 1A (Cyp1a) was assessed in the livers of eight flounder randomly selected from each treatment. Total RNA was isolated following standard protocols. Total RNA was assessed via NanoDrop spectrophotometer for quality and concentration, and acceptable samples were reverse transcribed to cDNA using a Revertaid kit. Species-specific primers for Cyp1a were used for qPCR analysis, and gene induction was expressed as fold change from control values (normalized to $18 \mathrm{~S}$ expression levels) using the Sybr Select Master Mix and an ABI 7500 Fast Real Time PCR instrument.

\subsection{DNA Extraction}

Tissue samples from the top gill, bottom gill, and intestine of flounder from the $54 \mathrm{mg} / \mathrm{kg}$ treatment $(\mathrm{N}=8)$ and control treatment $(\mathrm{N}=8)$ were analyzed for variation in the organ-specific microbial communities associated with oil exposure. DNA was extracted from gill and liver tissues using a PowerSoil DNA Isolation Kit (MoBio Laboratories). A thoroughly homogenized aliquot of each tissue sample was added to the PowerSoil bead tube. Extraction proceeded per the directions in the kit resulting in $100 \mu$ of DNA in elution buffer (10 mM Tris). Concentrations of DNA in each sample were measured and recorded using a NanoDrop Spectrophotometer (Thermo) to account for total DNA used in qPCR.

\subsection{Microbial Diversity Analysis}

The relationship between microbial communities in intestine and gill tissues of oil vs. non-oil exposed fish was determined by 16S rRNA gene amplification and sequencing as described by Dowd et al. (Dowd et al., 2008), targeting the V1-V3 region. Sequences that failed to return at least half the expected amplicon length (or $250 \mathrm{bp}$, whichever was shortest) were removed from the data pool. All sequences were then denoised using an algorithm based on USEARCH 
(Edgar, 2010) and checked for chimeras using UCHIME (Edgar et al., 2011). After denoising and chimera checking, sequence data were separated into operational taxonomic units (OTUs) and annotated using the RDP classifier (Wang et al., 2007) with GreenGenes v. 12.10 (McDonald et al., 2012) used as a reference. Finally, relative abundances of taxa at each hierarchical taxonomic level were calculated using the summarize_taxa.py QIIME script. Of 952 OTUs, 590 mapped to known taxonomic assignments (minimum 97\% similarity). Those OTUs that failed to match were excluded from further analyses. Negative binomial generalized linear models were performed with the Deseq2 package within R (Anders and Huber, 2010; Love et al., 2014; R Core Team, 2013). Oiling treatment effects were statistically analyzed with a Wald test with Benjamini-Hochberg correction. Alpha values for the Benjamini-Hochberg adjusted p-values were set at 0.1 . Community composition analysis was performed via a distance-based redundancy analysis (db-RDA) with oil treatment and tissue (upper gill, lower gill, and intestine) as constraining factors.

\subsection{Predictive Metagenomic Analysis}

Closed-reference OTUs were picked from the Green Genes database (v13.5) with QIIME (v1.8.0) at 97\% identity (Caporaso et al., 2010). Metagenome predictions were calculated with PiCRUSt (Phylogenetic Investigation of Communities by Reconstruction of Unobserved States, v1.0.0 (Langille et al., 2013)). From 890 OTUs, 6,909 pathways were calculated with 21,940,124 individual predicted gene counts. The average Nearest Sequenced Taxon Index (NSTI) for oiled and non-oiled samples for the metagenomic predictions was $0.14 \pm 0.05$. Lower NSTI values indicate that microbes in a given sample are more closely related to sequenced genomes (Langille et al., 2013). Our NSTI values were consistent with previous work (Langille et al., 2013) which revealed higher NSTI values in mammalian guts $(0.14 \pm 0.06)$ and environmental 
communities $(0.17 \pm 0.02)$. The predicted Kyoto Encyclopedia of Genes (KEGG) pathways were collapsed down to level 3 KEGG Orthology groups (KOs) with the PiCRUSt script categorize_by_function.py. Negative binomial generalized linear models were fit to the predicted KOs of the microbiota samples. Alpha values for Benjamini-Hochberg adjusted pvalues were set at 0.1 .

\subsection{Statistical Analysis}

Log-logistic dose-response curves were fitted for mortality, growth, and histopathologic effects using the $d r c$ package (Ritz, 2010; Ritz and Streibig, 2005). Effect concentrations (LC and EC) and confidence intervals were estimated based on the profile-likelihood (Faraggi et al., 2003; Venzon and Moolgavkar, 1988) using the bbmle package (Bolker, 2013; R Development Core Team, 2013). The LC estimates reported account for control mortality. For growth endpoints, reported $\mathrm{EC}_{20}$ and $\mathrm{EC}_{50}$ represent the exposure concentrations associated with $20 \%$ and $50 \%$ decreases relative to control growth, respectively. For histology endpoints, $\mathrm{EC}_{20}$ and $\mathrm{EC}_{50}$ represent the concentrations associated with $20 \%$ and $50 \%$, respectively, of the difference between the control and the maximum response. We report LOECs for reduction in macrovesicular vacuolation and hepatosomatic indices because intermediate responses were not observed for these endpoints. These analyses were all performed in $\mathrm{R}$ using version 3.1.1 ( $\mathrm{R}$ Core Team, 2013).

Differences in the percentage of swollen lamellae and the rank value of telangiectasia among treatments were tested using ANOVA with Bonferroni post-hoc analysis. Percentage values were arcsine squareroot transformed prior to analysis, and homogeneity of variance was tested using Levene's Test. These analyses were performed in SPSS, version 18. Gene expression of Cyp1a between treatments was expressed as fold-change from control values as Relative Quantitation 
implemented in the ABI Data Assist v. 3.01 software. In all cases, differences were considered significant if $\mathrm{p}<0.05$.

\subsection{Results and Discussion}

\subsection{Sediment and PAH Characterizations and Concentrations}

The sediments used in this study were dominated by sands and silts with grain size $<0.5 \mathrm{~mm}$ (Table S2). There was a slight increase in TOC of control sediments from experiment initiation $(0.505 \%)$ until experiment termination (0.594\% TOC).

The process of mixing Slick B oil into sediment did not change the composition of the PAHs (Figure S1A). Phenanthrenes/anthracenes remained the most common component of the complex oil mixture, with flourenes, dibenzothiophenes, chrysenes and pyrenes each contributing $>2 \%$ to the PAH composition. This PAH distribution is similar to that seen in sediments collected near the DWH wellhead one year after the DWH blow-out as well as in estuarine sediments several months following the blowout (Liu et al., 2012), suggesting that the mixed sediments used for this experiment are therefore a valid proxy for estuarine sediments contaminated with oil from the DWH incident. Furthermore, the similarity between the PAH profiles in Slick B samples and the PAH profiles from the sediment mixed with different amounts of Slick B demonstrate that the mixing process did not alter the relative proportion of PAHs. Nominal and measured PAH concentrations were similar (Figure S1B), and show that the mixing process was also successful in producing the targeted sediment concentrations. The sum of 50 individual PAH concentration measurements (tPAH50) in the sediments of the different treatments were 0.03 , $0.7,8,52,127$, and $395 \mathrm{mg} / \mathrm{kg}$ sediment at experiment initiation. The tPAH50 concentration of 
the sediments decreased little over the 32 day experiment (Table S1) despite constant renewal of clean water into the system.

The tPAH50 concentration of the unfiltered water overlying the sediments was $<5 \mu \mathrm{g} / \mathrm{L}$ in all but the highest treatment throughout the study (Figure S1C), confirming that the majority of the oil remained in the sediments for the duration of the study. Furthermore, tPAH50 composition in the water column and the sediments were similar, suggesting any PAHs in the water column likely came from oil-bound suspended fine grain material and not dissolved constituents. Measured tPAH50 of water overlying the highest treatment $(395 \mathrm{mg} / \mathrm{kg}$ in sediment) peaked at $45 \mu \mathrm{g} / \mathrm{L}$ at day 2 and declined to $10 \mu \mathrm{g} / \mathrm{L}$ by day 10 of the experiment. No further measurements were taken from this treatment, as 94\% of the flounder in this treatment died by day 11 . Fluorescence measurements showed that variability in PAH concentrations of replicate aquaria within treatments was minimal, and also showed little decrease in PAH concentrations of overlying water across treatments during the course of the experiment (Figure S1D). As there was little release of PAHs into the water column throughout the 32 day experiment, the observed effects on exposed flounder are likely due to sediment-associated PAHs, rather than aqueous PAHs. These data suggest that sediment-associated PAHs are likely to remain a contaminant of concern for benthic organisms in the area affected by DWH for years after the spill. Recent analyses of DWH-oiled sediments from Louisiana marshes confirms minimal degradation of PAHs three years post-spill (Turner et al., 2014). Long-term persistence of oil in intertidal sediments following the 1989 Exxon Valdez oil spill has resulted in delayed recovery of benthic marine communities, which can have ecosystem-wide implications (Ballachey et al., 2014; Peterson et al., 2003).

\subsection{Mortality and Growth}


Flounder mortality increased with increasing concentrations of oil in sediments, and no mortality was observed in control treatments (Figure 1A). Some fish in the highest concentration (395 $\mathrm{mg} / \mathrm{kg}$ tPAH50) died within $24 \mathrm{~h}$ of exposure or appeared lethargic, and by day 18 of the experiment all fish in this treatment were dead. The $\mathrm{LC}_{50}$ for the 32 day exposure was 78.1 $\mathrm{mg} / \mathrm{kg}$ tPAH50 $(95 \%$ confidence intervals $=56.6,104 \mathrm{mg} / \mathrm{kg})$, and the associated $\mathrm{LC}_{20}$ was 36.3 $\mathrm{mg} / \mathrm{kg}$ tPAH50 $(95 \% \mathrm{CI}=20.2,54.7)$. These calculated LC values are within the range of concentrations of oil range organics found in sediments along coastal Mississippi and Alabama 3 months after capping the flow from the DWH spill (55-75 mg/kg; (Floyd et al., 2012)), suggesting benthic fishes along the north central GOM coast in summer and fall 2010 were likely impacted by the DWH oil spill. 

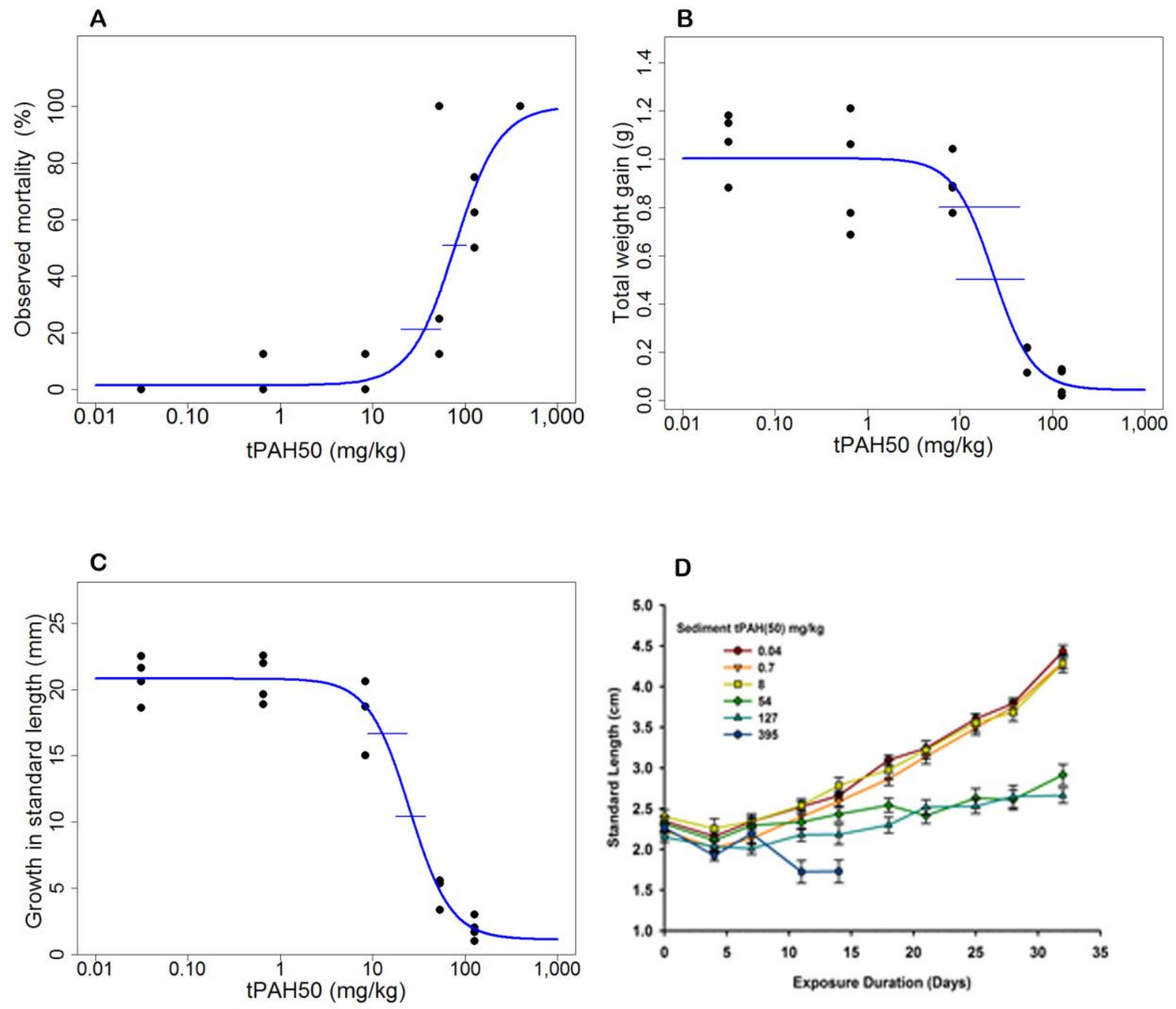

Figure 1. Mortality and growth of southern flounder exposed to various concentrations of oiled sediments for $32 \mathrm{~d}$. Dose-response relationship between exposure concentration and mortality (A), total weight in grams (B) and change in standard length (SL) in mm (C). Points indicate mean values per replicate tank. Upper and lower horizontal lines indicate the $95 \%$ confidence intervals on estimated $\mathrm{LC} / \mathrm{EC}_{20}$ and $\mathrm{LC} / \mathrm{EC}_{50}$, respectively. $\mathrm{EC}$ values are based on the percent reduction from control mortality or growth. D. Mean $( \pm \mathrm{SE})$ length $(\mathrm{cm} \mathrm{SL})$ of flounder in each treatment. Measurements for Day 0 and Day 32 were taken directly on the fish with a ruler; other measurements were taken from video images.

There was wide variability in fish growth within all replicate aquaria (differences of 3 to $29 \mathrm{~mm}$ SL among individual fish in a single aquarium at the end of the study), but there was no trend in this variability associated with treatment. Increasing sediment concentrations of tPAH50 
reduced growth in both weight (Figure 1B) and length (Figure 1C). The effective concentrations (EC) impacting growth in weight were calculated as $\mathrm{EC}_{20}=12.0 \mathrm{mg} / \mathrm{kg}$ tPAH50 $(95 \% \mathrm{CI}=5.9$, 44.3) and $\mathrm{EC}_{50}=23.9 \mathrm{mg} / \mathrm{kg}$ tPAH50 (95\% CI = 9.0, 49.6) (Figure 1B). Similarly, concentrations impacting growth in length were $\mathrm{EC}_{20}=12.8 \mathrm{mg} / \mathrm{kg}$ tPAH50 $(95 \% \mathrm{CI}=8.8,23.7)$ and $\mathrm{EC}_{50}=26.7 \mathrm{mg} / \mathrm{kg}$ tPAH50 $(95 \% \mathrm{CI}=17.6,37.4)$ (Figure 1C). The contaminant-related reduction in growth was evident early in the experiment; after $10 \mathrm{~d}$ exposure to $395 \mathrm{mg} / \mathrm{kg}$ tPAH50 and after 14 days of exposure to concentrations $>8 \mathrm{mg} / \mathrm{kg}$ (Figure 1D). Similar results have been shown for other benthic species; four species of juvenile flatfishes showed significantly reduced growth after 90 days exposure to oiled sediments (Moles and Norcross, 1998), and juvenile brown shrimp (Farfantepenaeus aztecus) grew slower after seven days exposure to heavily DWH-oiled sediments (Rozas et al., 2014).

\subsection{Histopathologic Analyses}

Histopathologic examination revealed only occasional mild evidence of background disease in both control and treated flounder indicating that the histopathologic changes reported were a result of exposure to oil-contaminated. Histopathologic conditions and consensus scores for kidney, heart, liver and gill tissues from controls and four treatments are listed in Table S3; fish from the highest treatment were not analyzed due to mortality prior to experiment termination. Kidney tissue showed mild tubule proliferation and/or granuloma in some specimens from every oiled sediment treatment, but these observations showed no strong relationship to increasing sediment tPAH50 concentration and can be considered background lesions present in all fish. Atrophy of myocardial trabeculae was observed in heart tissue from one specimen each in the $0.7,8$ and $54 \mathrm{mg} / \mathrm{kg}$ tPAH50 treatments, and increased edema was noted in heart tissue in some specimens from all oiled sediment treatments. Recent evidence shows disruption of 
cardiomyocyte repolarization in heart tissue (Brette et al., 2014) and defects in heart development of larval marine fishes exposed to DWH oil (Incardona et al., 2014). Furthermore, embryonic zebrafish exposed for $48 \mathrm{~h}$ to oiled water exhibited changes in heart shape and reduced cardiac output as adults (Hicken et al., 2011). Therefore, in light of this information, the mild histopathologic changes in heart tissue of juvenile flounder exposed to oiled sediments reported here warrants further investigation.

Distinct histopathologic effects of oiled sediment exposure in flounder were seen in liver and gill tissues. Flounder exposed to non-oiled sediments exhibited healthy hepatocytes and exocrine pancreatic tissue (Figure 2A). There was a reduction in exocrine pancreatic tissue in fish exposed to 54 and $127 \mathrm{mg} / \mathrm{kg}$ tPAH50 oiled sediments (Table S3), although diseased or atrophied exocrine pancreatic tissue was not observed in fish exposed to oiled sediments $>8 \mathrm{mg} / \mathrm{kg}$ tPAH50. A loss of zymogen granules in the cytoplasm of acinar cells in the pancreas, which can result in reduction of pancreatic tissue, is often observed during starvation (Zachary and McGavin, 2012). In addition, some exocrine pancreatic tissue in flounder from $8 \mathrm{mg} / \mathrm{kg}$ and 127 $\mathrm{mg} / \mathrm{kg}$ exhibited large eosinophilic inclusions in the duct lumens/cells (Figure S2), likely containing cellular debris and pancreatic enzymes (Zachary and McGavin, 2012). Hepatic edema, characterized by curved and branching interlobular vascular profiles and perivascular sinusoidal ectasia, was observed in flounder from all treatments including control, but hepatic edema prevalence was higher in flounder exposed to oiled sediments containing $\geq 1 \mathrm{mg} / \mathrm{kg}$ tPAH50 (Table S3). 
A

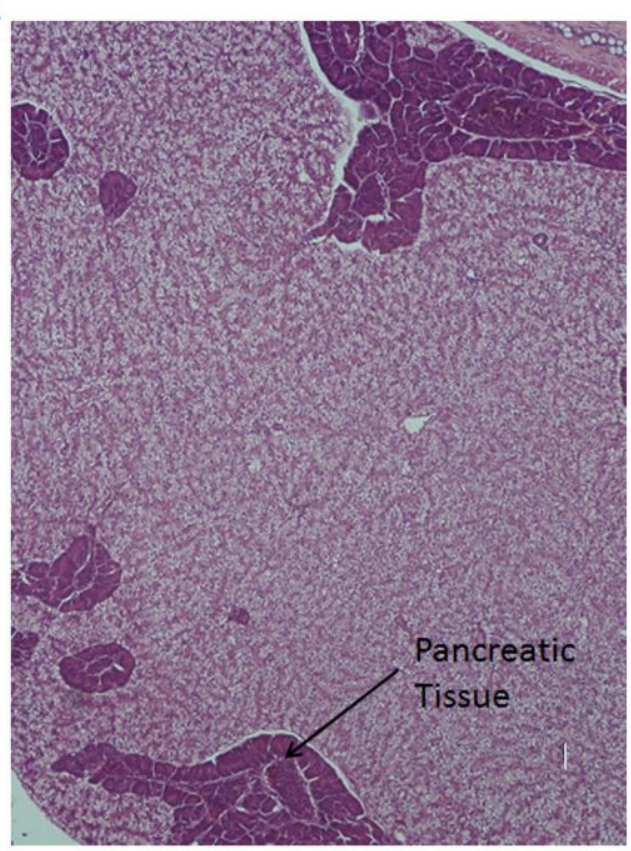

C

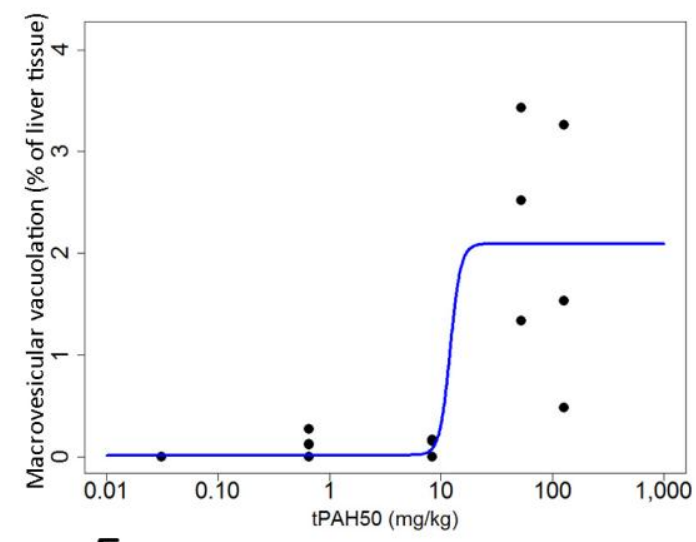

E

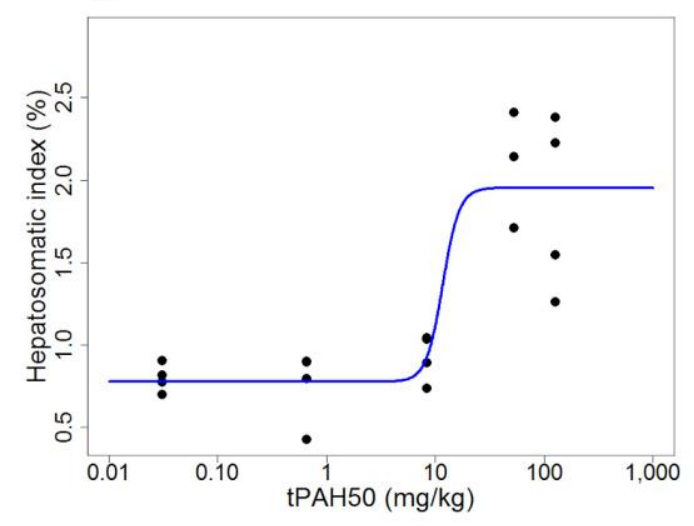

B

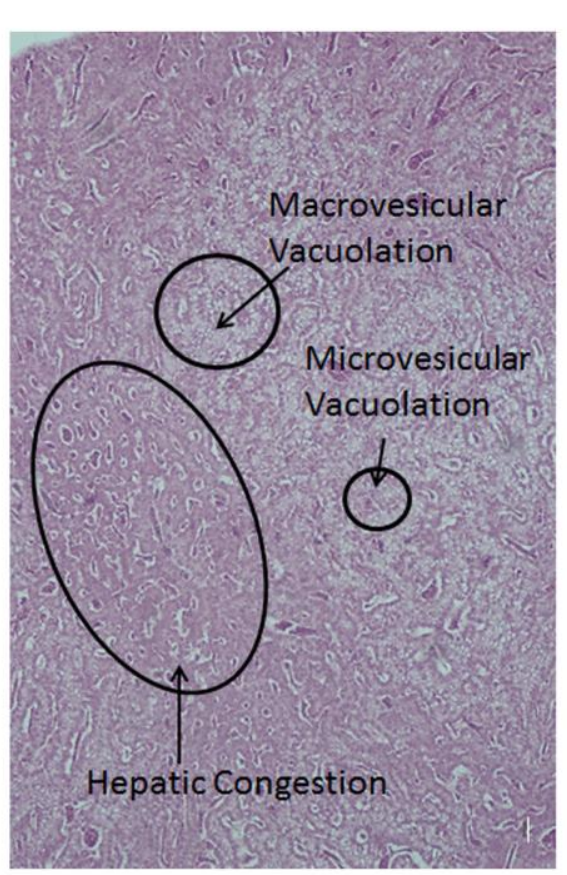

D

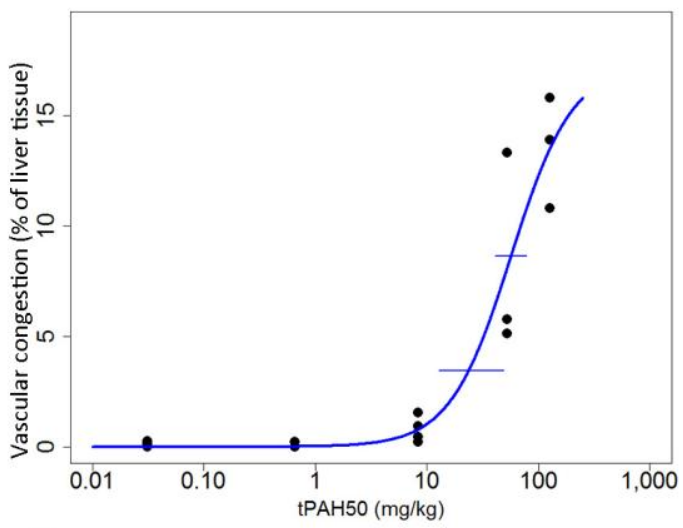

$\mathbf{F}$

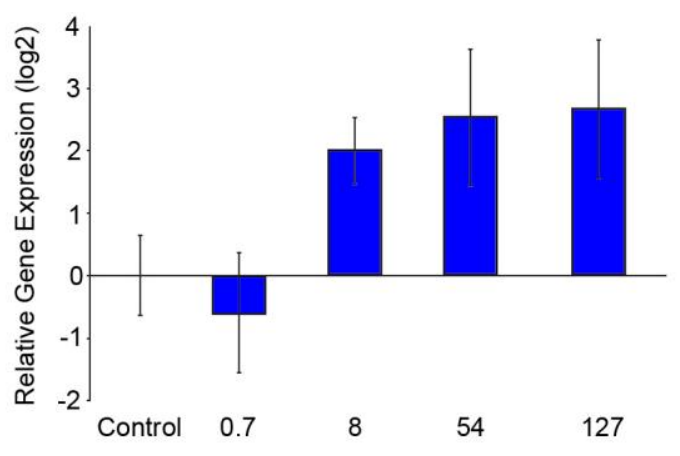

Figure 2. Effects of exposure to oiled sediment for 32 days on hepatic tissue of southern flounder. A. Histological section of normal liver tissue from control fish. Bar $=100 \mu \mathrm{m}$. B. 
Histological section of liver tissue from flounder exposed to oiled sediment ( $54 \mathrm{mg} / \mathrm{kg}$ tPAH50). Bar $=100 \mu \mathrm{m}$. Pathological responses include macrovesicular vacuolation, microvesicular vacuolation and hepatic vascular congestion. C. Relationship between sediment tPAH50 concentration and the extent of hepatic tissue showing macrovesicular vacuolation. D. Relationship between sediment tPAH50 concentration and the extent of hepatic tissue affected by vascular congestion. Upper and lower horizontal lines indicate the $95 \%$ confidence intervals on estimated $\mathrm{LC} / \mathrm{EC}_{20}$ and $\mathrm{LC}_{\mathrm{E}} \mathrm{EC}_{50}$, respectively. E. Relationship between sediment tPAH50 concentration and Hepatosomatic Index (HSI) of flounder. F. Relative expression of Cyp1a in liver tissues of flounder exposed to various concentrations of oiled sediments for 32 days. For all dose response curves, EC values are based on the range of response.

Overall, changes in hepatic structure were the most marked histopathologic indicators of oiled sediment exposure. Hepatocellular vacuolation was evident in fish exposed to all oiled sediment treatments but was not evident in control fish (Figure 2B). All fish exposed to oiled sediment concentrations $>8 \mathrm{mg} / \mathrm{kg}$ tPAH50 exhibited some micro- and macro-vesicular vacuolation; dose response curves show the $\mathrm{EC}_{50}$ for this lesion is $12.09 \mathrm{mg} / \mathrm{kg} \mathrm{tPAH} 50$, although intermediate responses were not observed for this endpoint and thus 95\% CI could not be calculated (Figure 2C). In addition, increasing tPAH50 concentration resulted in increasing occurrence of hepatic vascular congestion $\left(\mathrm{EC}_{20}=23.76 \mathrm{mg} / \mathrm{kg} \mathrm{tPAH} 50,95 \% \mathrm{CI}=12.85,48.71 ; \mathrm{EC}_{50}=57.03 \mathrm{mg} / \mathrm{kg}\right.$ tPAH50, 95\% CI = 40.65, 78.58; Figure 2D). At the highest exposure concentration $(127 \mathrm{mg} / \mathrm{kg}$ tPAH50), $13.04 \pm 2.43 \%$ of the liver tissue in all fish exhibited hepatic vascular congestion.

Increases in hepatic congestion and macro- and micro-vesicular hepatocellular vacuolation are recognized responses to $\mathrm{PAH}-\mathrm{contaminated} \mathrm{sediment} \mathrm{exposure} \mathrm{in} \mathrm{benthic} \mathrm{fishes} \mathrm{(Cachot} \mathrm{et} \mathrm{al.,}$ 2013; Costa et al., 2009; Moles and Norcross, 1998; Myers et al., 2003). Increases in both hepatic glycogen content (microvesicular vacuolation, most common in flounder exposed to 8 $\mathrm{mg} / \mathrm{kg}$ tPAH50) and hepatic lipid content (macrovesicular vacuolation, most common in flounder exposed to 52 and $127 \mathrm{mg} / \mathrm{kg}$ tPAH50) are reported to be inducible by exposure to toxins in 
several fish species (Wolf and Wolfe, 2005), consistent with our findings. In addition, the observed changes in liver histopathology suggest malabsorption and a negative energy balance in flounder exposed to higher oiled sediment concentrations during the 32 day experiment, as macrovesicular vacuolation is symptomatic of sick, stressed or malnourished fish (Wolf et al., 2014a). Similar histopathologic changes were shown in liver of fasting European sea bass (Dicentrarchus labrax; (Gambardella et al., 2012); upon refeeding, liver histopathology returned to normal. The reduced growth observed in flounder at concentrations $>8 \mathrm{mg} / \mathrm{kg}$ tPAH50 (Figure 1C-D) was in conjunction with evidence from histopathologic examination of stomachs and intestines of reduced feeding at the higher concentrations. Food was observed to be present in $100 \%$ of the individuals exposed to $<8 \mathrm{mg} / \mathrm{kg}$ tPAH50, while some fish at higher concentrations had no food in the stomach (Table S4). Furthermore, control fish and those exposed to 0.7 $\mathrm{mg} / \mathrm{kg}$ tPAH50 had large amounts of food present in the intestine, while there was no food in the intestine of $90 \%$ of the flounder exposed to 54 and $127 \mathrm{mg} / \mathrm{kg}$ tPAH50. While the oiled sediments may not directly cause the observed hepatic histopathologic changes, flounder exposed to $>8 \mathrm{mg} / \mathrm{kg}$ tPAH50 appear to have decreased feeding during the course of the experiment, consistent with the histopathologic changes observed in the liver.

The Hepatosomatic Index $\left(\mathrm{HSI}=[\mathrm{LW} / \mathrm{W}]^{* 100}\right)$ values of flounders also showed a doseresponse relationship to oiled sediment concentration $\left(\mathrm{EC}_{50}=10.66 \mathrm{mg} / \mathrm{kg}\right.$ tPAH50; Figure $\left.2 \mathrm{E}\right)$, although intermediate responses were not observed for this endpoint and 95\% CI could not be calculated. Elevated HSI values have been reported previously in four species of field-collected flounders exposed to petroleum or PAHs compared to control areas (Kahn, 1995; Kleinkauf et al., 2004), suggesting this is a common response. Indeed, histopathologic observations in this study suggest an accumulation of glycogen and/or lipids at the highest treatment concentrations; 
lipid or glycogen vacuolization has been shown to increase the size of hepatocytes (Wolf and Wolfe, 2005) which would therefore increase the HSI value.

Flounder exposed to non-oiled sediments exhibited low occurrence of gill abnormalities such as swollen or fused lamellae and epithelial proliferation on gill lamellae (Figure 3A). A much higher percentage of flounder exhibited swollen or fused gill lamellae at the highest oiledsediment concentrations (Table S2, Figure 3B), and this lesion is significantly dose dependent (ANOVA, $F_{4,51}=19.39, p<0.001$, Figure S3A). Similar results have been reported for six other species of juvenile and adult flatfish exposed to oiled sediments (Costa et al., 2009; Kahn, 1995; Moles and Norcross, 1998). Epithelial cell proliferation of gill lamellae (Figure 3B) appears to be very sensitive to oiled sediments, with dose-response curves showing $\mathrm{EC}_{20}=0.29 \mathrm{mg} / \mathrm{kg}$ tPAH50 (95\% CI $=0.0,7.2)$ and $\mathrm{EC}_{50}=3.07 \mathrm{mg} / \mathrm{kg}$ tPAH50 (95\% CI $=1.04,8.64 ;$ Figure 3C). Similar proliferation was observed in the gills of plaice (Pleuronectes platessa) (Haensly et al., 1982) as well as juvenile and adult winter founder (P. americanus) exposed to oiled sediments (Kahn, 1995). A similar increase in the percentage of secondary lamellae showing telangiectasia (Figure 3B) with exposure to oiled sediments was observed (Figure 3D), and this endpoint was also sensitive to oiled sediment concentrations $\left(\mathrm{EC}_{20}=1.34 \mathrm{mg} / \mathrm{kg}\right.$ tPAH50, 95\% CI $=0.15$, $6.35 ; \mathrm{EC}_{50}=6.30 \mathrm{mg} / \mathrm{kg}$ tPAH50, 95\% $\left.\mathrm{CI}=2.35,16.09\right)$. Telangiectasia is characterized by club shaped expansion of the secondary lamellae caused by microaneurysms in the distal gill capillaries. There was also a significant (ANOVA, $\left.\mathrm{F}_{4,51}=16.56, \mathrm{p}<0.001\right)$ difference in the rank value of telangiectasia (from $0.40 \pm 0.04$ to $1.40 \pm 0.26$; Figure S3B) as oil concentrations increased. These results indicate that not only did a greater percentage of lamellae have secondary lamellae exhibiting telangiectasia in the higher oil concentrations, but the severity of the condition also increased in the higher oil concentrations, from a mean of $\sim 12.5 \%$ of the 
secondary lamellae exhibiting telangiectasia in controls to a mean of $\sim 37.5 \%$ of the secondary lamellae exhibiting the condition in the highest oil concentration. Euthanasia using MS222 in ice water can impact the secondary lamellae of gill tissue resulting in telangiectasia (Wolf et al., 2014a; Wolf et al., 2014b), and this may explain the relatively high percentage of control fish with telangiectasia in this study; however, the marked increase in the percentage of gill tissue displaying telangiectasia in the higher treatments suggests a treatment effect above background levels. Telangiectasia has also been reported in secondary lamellae of adult plaice and winter flounder exposed to oil contaminated sediments (Haensly et al., 1982; Khan, 2003). Overall, the marked changes in the gills at the highest oiled sediment concentrations suggest a profound impairment of gas exchange, resulting in increased energy expenses to support oxygen demand with damaged gills (Ferguson, 2006). Since morphological change lags far behind functional impairment (Ferguson, 2006), even subtle changes in gill tissue may impact gas exchange, contributing to the increased mortality seen at the higher oiled sediment concentrations. 


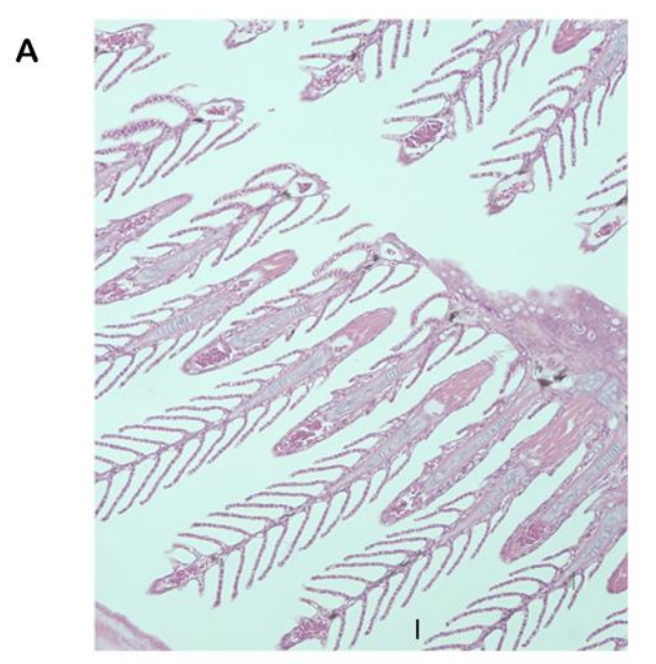

C

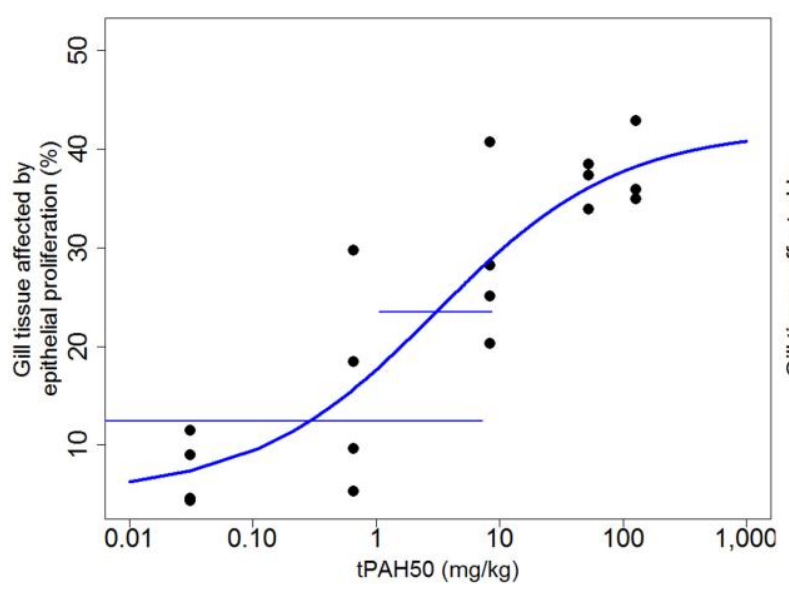

B

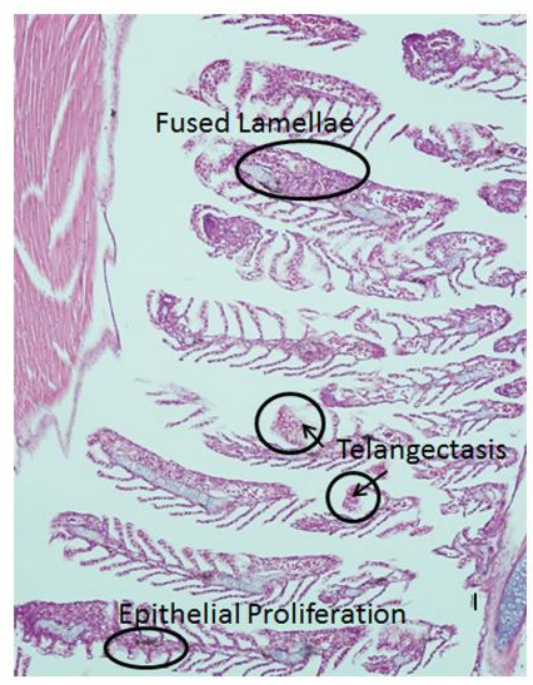

D

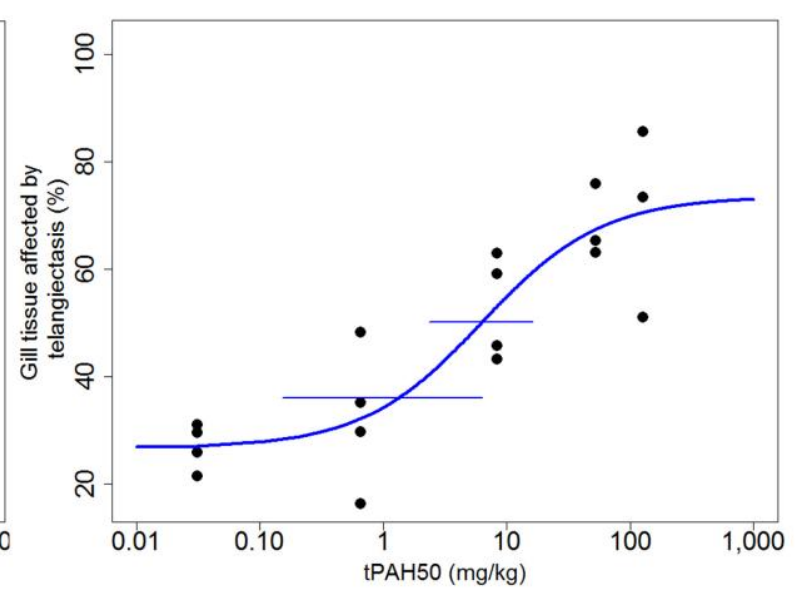

Figure 3. Histopathologic effects on southern flounder gill tissue after 32 days of exposure to oiled sediment. A. Photomicrograph of normal gill tissue from control fish. Bar $=100 \mu \mathrm{m}$. B. Photomicrograph of gill tissue from flounder exposed to oiled sediments (127 mg/kg tPAH50). Bar $=100 \mu \mathrm{m}$. Pathological responses include fused secondary lamellae, telangiectasis of secondary lamellae, and epithelial proliferation along the lamellae. C. Relationship between sediment tPAH50 concentration and the extent of gill tissue affected by epithelial proliferation D. Relationship between sediment tPAH50 concentration and the extent of gill tissue exhibiting telangiectasis. For dose-response curves, points indicate mean values per replicate tank. Lower and upper horizontal lines indicate the $95 \%$ confidence intervals on estimated $\mathrm{EC}_{20}$ and $\mathrm{EC}_{50}$, respectively. EC values are based on the range of response. 


\subsection{Gene Expression}

Expression of Cyp1a in hepatic tissue was dose-dependent following 32 days exposure to oiled sediments. Control flounder, as well as those exposed to $0.7 \mathrm{mg} / \mathrm{kg}$ tPAH50, showed no expression of Cyp1a. Exposure to oiled sediments $>8 \mathrm{mg} / \mathrm{kg}$ tPAH resulted in a dose-dependent increase in expression of CYP1A, with greater expression evident at higher concentrations (Figure 2F). Increased expression of Cyp1a is a common biomarker for exposure to hydrocarbons (Hylland, 2006; Sarasquete and Segner, 2000), and provides evidence that the adverse effects reported here are a function of oil exposure. Induced Cyp1a expression has also been documented in other flatfish species exposed to oiled sediments (Myers et al., 2003; Roy et al., 2003).

\subsection{Commensal Microbial Population Analysis}

In addition to the primary effects of sediment associated PAHs on flounder, we observed significant shifts in commensal assemblages of gill and intestinal bacteria in flounder exposed to oil-contaminated sediment. Distance-based redundancy (db-RDA) analysis indicated a strong and statistically significant shift in microbial communities in both organs following oil exposure (Figure 4). Oiling treatment and host tissue type were significant drivers in differentiating microbiota composition but not the interaction of tissue type and oil treatment (Permutation ANOVA on db-RDA constraints; Host tissue type: $\mathrm{df}=2, \mathrm{~F}=4.513, \mathrm{p}=0.01$, Oil: $\mathrm{df}=1, \mathrm{~F}=$ 3.921, $\mathrm{p} \mathrm{e}=0.02$, Oil $x$ Tissue: $\mathrm{df}=2, \mathrm{~F}=1.031, \mathrm{p}=0.38$ ). 


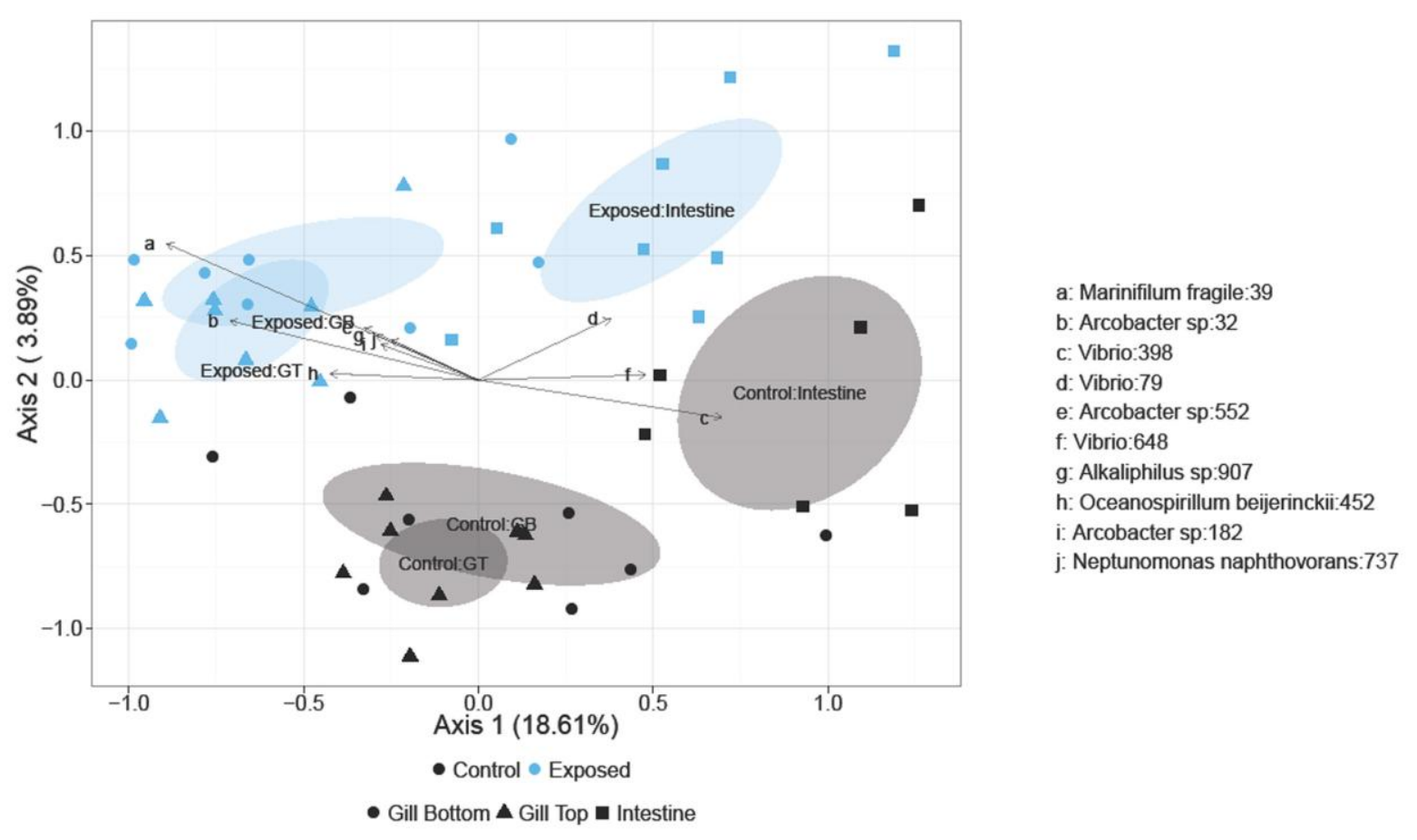

Figure 4. Principal Coordinate Analysis plot of bacterial communities in top gill (GT), bottom gill (GB) and intestinal tissues of southern flounder exposed to control and oiled sediments (54 $\mathrm{mg}$ tPAH50/kg). Vector length and direction are indicative of the relative contribution of bacterial species to the ordination.

Overall, Gammaproteobacteria (47.06 $\pm 8.87 \%)$, Sphingobacteria $(9.03 \pm 2.16 \%)$,

Deltaproteobacteria $(8.05 \pm 2.94 \%)$, and Epsilonproteobacteria $(9.77 \pm 2.86 \%)$ increased in intestinal microbiota of host fish exposed to oil, while Alphaproteobacteria $(13.72 \pm 3.96 \%)$ and Clostridia $(5.08 \pm 1.73 \%)$ decreased. A total of 37 Operational Taxonomic Units (OTUs) had altered abundances in oil-exposed hosts. Of those 37 OTUs, 12 increased in abundance (Figure 5A). The 12 over abundant OTUs included members from Alcanivorax, Arcobacter, unidentified members of Rhodovacteraceae, Pseudoaltermonas, Oceanospirillales, and Donghicola. Owenweeksia hongkongensis was reduced greatly (-24.98 $\pm 2.875 \log _{2}$ fold change). 

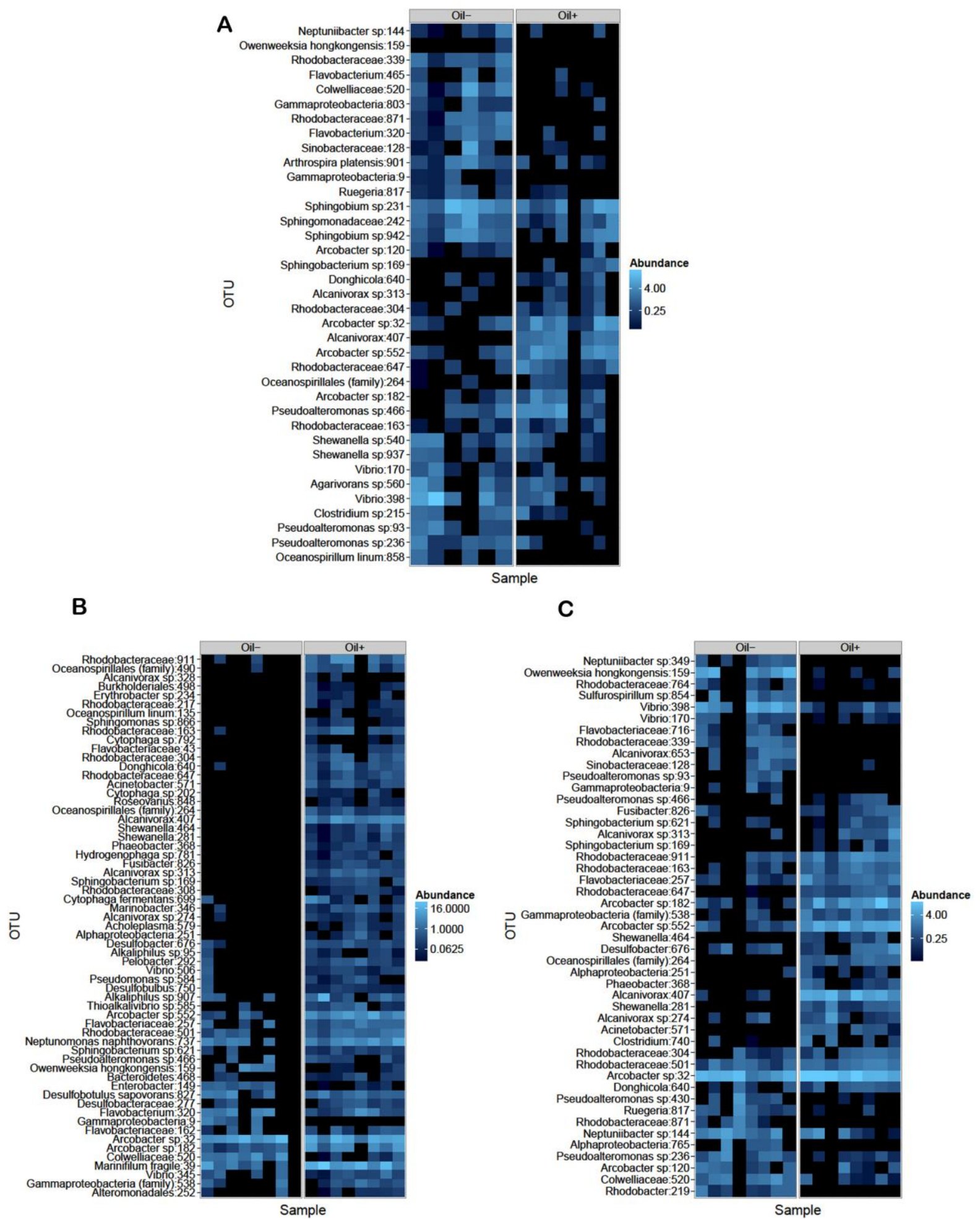

Figure 5. Microbial communities significantly affected by oil exposure. Color scale indicates Operational Taxonomic Unit (OTU) abundance. A. Intestinal OTUs affected. B. Lower gill OTUs affected. C. Upper gill OTUs affected. 
Oil exposure affected the microbial assemblages on lower gills differently than upper gills. Sixty-one OTUs in lower gills changed in abundance compared to 47 in the upper gills. Both top and bottom gill microbial assemblages were more sensitive to oiling exposure than the intestinal microbial communities. In microbiota associated with lower gill tissue, only four OTUs were reduced in abundance, including Owenweeksia hongkongensis (-7.061 $\pm 2.010 \log _{2}$ fold change), which also was reduced in upper gills (-12.047 $\pm 1.996 \log _{2}$ fold change). Alcanivorax, Cytophaga, Acinetobacter, Rhodobacteraceae and Oceanospirillum linum were among the OTUs that had the highest $\log _{2}$ fold change due to oiling in lower gill microbiota (Figure 5B). OTUs that had the highest increase in $\log _{2}$ fold change abundance in upper gills also included Alcanivorax, Acinetobacter, Shewanella, Oceanospirillales, and Phaeobacter (Figure 5C).

\subsection{Predictive Metagonomics Analysis}

The slight differences between upper and lower gills were echoed in the predictive metagenomic analysis. Bottom gills had 95 level-3 KEGG pathways that were differentially abundant, and upper gills had 41. There were no significant changes in the abundance of level-3 KEGG pathways between control and oiled exposed gut microbiomes.

Of the 14 pathways that were overly abundant in upper gill-associated microbiota, 11 were involved in metabolism, one in environmental information processing, one in human diseases (distant enzymatic homolog), and one unclassified. Xylene, atrazine, dioxin, and bisphenol degradation had the greatest increase in $\log _{2}$ fold change (Figure 6A). Pathways that were reduced in abundance due to oiling also included metabolism $(n=15)$, environmental information processing $(n=2)$, human diseases $(n=3)$, unclassified $(n=5)$, and organismal systems ( $\mathrm{n}=2)$. Caffeine metabolism, enzymatic pathways associated with Staphylococcus aureus infection, and secondary bile acid biosynthesis were some of the most reduced pathways. 
A
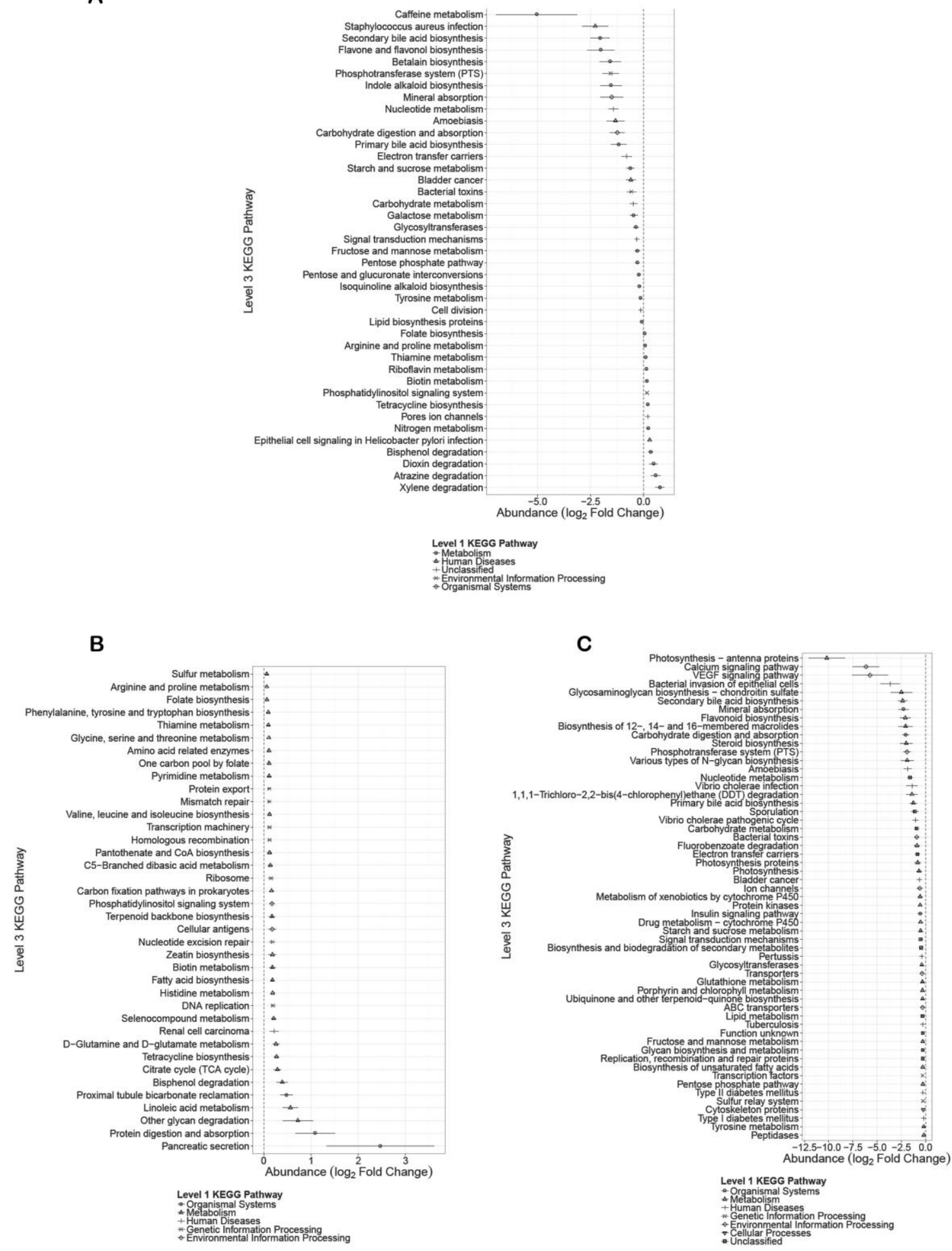

Figure 6. Predictive metagenomics analysis of the bacterial taxa affected by oil exposure. A. Pathways differentially affected by oil exposure in upper gill. B. Pathways overrepresented in lower gills exposed to oil. C. Pathways underrepresented in lower gills exposed to oil. 
Of the 95 predicted differentially abundant pathways found in lower gill microbiota, 38 were overly abundant. The 38 level-1 KEGG pathways that were overly abundant were represented under metabolism $(n=25)$, genetic information processing $(n=7)$, organismal systems $(n=3)$, environmental information processing $(n=2)$ and human diseases $(n=1)$. Level-1 KEGG pathways that were reduced in abundance included metabolism $(n=25)$, unclassified $(n=10)$, human diseases $(n=9)$, environmental information processing $(n=7)$, organismal systems $(n=$ 3), genetic information processing $(n=2)$, and cellular processes $(n=1)$. At level-3, the bisphenol degradation pathways again had one of the highest $\log _{2}$ fold increases, with distant homolog enzymatic pathways to pancreatic secretion, DNA replication, nucleotide excision repair, and transcription machinery (Figure 6B). Pathways that had the greatest reduction in $\log _{2}$ abundance included photosythesis, calcium signaling and vascular endothelial growth factor (VEGF) signaling pathways (Figure 6C).

Very little is known about the functions of bacteria that were affected in this study, and even less about their role in marine fish. It is therefore difficult to state the definite effects of the observed oil-induced microbiome shifts on fish health with any certainty. However, in both gills and intestines, several of the bacterial taxa that increased the most (Alcanivorax, Arcobacter, Donghicola, and Acinetobacter) have all been shown to be involved in degradation of hydrocarbons (Harayama et al., 2004; Liu et al., 2009; Liu and Liu, 2013; Sabirova et al., 2006; Schneiker et al., 2006; Tan et al., 2009). This is an obvious response to the hydrocarboncontaminated sediment exposure, and suggests that the contaminant-induced response is best viewed in terms of the host:bacteria system, rather than that of the host organism alone.

There is increasing evidence that microbial communities play an important role in mediating or influencing organism:chemical interactions. Changing the microbial community structure results 
in altered acetaminophen sulfonation kinetics in Sprague-Dawley rats (Clayton et al., 2009). Exposure to L-arginine has been shown to result in an increase in excretion of the gut microbial metabolites, suggesting an interaction between pancreatic function and microbiome activity in Spague-Dawley rats (Bohus et al., 2008), and exposure to TNBS has been shown to result in a microbiome-dependent shift in immune activity in zebrafish (Oehlers et al., 2011). Therefore, the observed oil-induced alterations in the microbial population structures of exposed flounder may produce a secondary adverse effect that is distinct from the primary effects of PAHs to the host organism itself, but also important to the health of the fish. This has important implications for aquatic toxicology, implying that examining the response of the fish alone may lead to an incomplete understanding of the effects of contaminants on aquatic organisms.

\subsection{Conclusion}

These results from a 32 day chronic exposure of juvenile southern flounder to environmentally relevant concentrations of sediment contaminated with naturally weathered oil show that oilcontaminated sediment is capable of causing severe adverse effects across multiple biological endpoints. The combination of increased mortality, decreased growth, histopathologic gill and liver changes indicating negative energy balance, and altered gill and intestinal microbiome structures with increasing PAH concentration in the sediment suggests system-wide impairment of important biological processes and alteration of energy budgets. Upregulation of CYP1A gene expression provides strong evidence that the oil was responsible for the observed effects. These data suggest that oil-contaminated sediments in the northern GOM are capable of causing adverse effects to exposed species. 


\subsection{Acknowledgments}

The authors thank B. Bailey, J.A. Jovonovich Alvillar, J.P. Lindsay, A.A. Karels, J. Johnson, L. Carigee, I. Lipton, D. Cacela, and A. McFadden for technical assistance with fish culture, data collection and sampling during experimentation, and data entry and organization. Philip Dixon was instrumental in construction of the logistic regression models. Histopathologic processing was completed at the VIBS Histology Laboratory, College of Veterinary Medicine, Texas A\&M University. We thank J. Fournie and L. Coffee for additional evaluation of the histological slides. National Oceanic and Atmospheric Administration National Ocean Service staff and contractors reviewed the experimental design and a draft of the manuscript. This work was supported by funds provided as part of the Natural Resource Damage Assessment (NRDA) for the DWH oil spill and was conducted under USM IACUC protocol number 11092204. Data presented here are a subset of a larger toxicological database that is being generated as part of the Deepwater Horizon Natural Resource Damage Assessment. Therefore, these data will be subject to additional analysis and interpretation which may include interpretation in the context of additional data not presented here. Funding played no role in the design or interpretation of these data. 


\subsection{Literature Cited}

Allan, S.E., Smith, B.W., Anderson, K.A., 2012. Impact of the Deepwater Horizon Oil Spill on Bioavailable Polycyclic Aromatic Hydrocarbons in Gulf of Mexico Coastal Waters. Environmental Science \& Technology 46, 2033-2039.

Almeda, R., Wambaugh, Z., Chai, C., Wang, Z.C., Liu, Z.F., Buskey, E.J., 2013. Effects of Crude Oil Exposure on Bioaccumulation of Polycyclic Aromatic Hydrocarbons and Survival of Adult and Larval Stages of Gelatinous Zooplankton. Plos One 8.

Anders, S., Huber, W., 2010. Differential expression analysis for sequence count data. Genome Biology 11, R106.

ASTM, 2007. Standard Test Method for Particle-Size Analysis of Soils. ASTM International, West Conshohocken, PA.

Ballachey, B.E., Bodkin, J.L., Esler, D., Rice, S.D., 2014. Lessons from the 1989 Exxon Valdez oil spill: a biological perspective., in: Alford, J.B., Peterson, M.S., Green, C.C. (Eds.), Impacts of Oil Spill Disasters on Marine Habitats and Fisheries in North America. CRC Press, Boca Raton, FL.

Bohus, E., Coen, M., Keun, H.C., Ebbels, T.M., Beckonert, O., Lindon, J.C., Holmes, E., Noszal, B., Nicholson, J.K., 2008. Temporal metabonomic modeling of l-arginine-induced exocrine pancreatitis. J Proteome Res 7, 4435-4445.

Bolker, B., R Development Core Team,, 2013. bbmle: Tools for General Maximum LIkelihood Estimation. R Package Version 1.0.15., Available: http://CRAN.RProject.org/package $=$ bbmle.

Brette, F., Machado, B., Cros, C., Incardona, J.P., Scholz, N.L., Block, B.A., 2014. Crude Oil Impairs Cardiac Excitation-Contraction Coupling in Fish. Science 343, 772-776.

Brewton, R.A., Fulford, R., Griffitt, R.J., 2013. Gene expression and growth as indicators of effects of the BP Deepwater Horizon oil spill on spotted seatrout (Cynoscion nebulosus). Journal of Toxicology and Environmental Health Part A 76, 1198-1209.

Brown-Peterson, N.J., R.A. Brewton, R.J. Griffitt and R.S. Fulford, 2014. Impacts of the Deepwater Horizon Oil Spill on the Reproductive Biology of Spotted Seatrout (Cynoscion nebulosus) in: Alford, B.A., M.S. Peterson and C. Green. (Ed.), Impacts of Oil Spill Disasters on Marine Fisheries in North America CRC Press, Boca Raton, FL, pp. 231-246.

Cachot, J., Cherel, Y., Larcher, T., Pfohl-Leszkowicz, A., Laroche, J., Quiniou, L., Morin, J., Schmitz, J., Burgeot, T., Pottier, D., 2013. Histopathological lesions and DNA adducts in the liver of European flounder (Platichthys flesus) collected in the Seine estuary versus two reference estuarine systems on the French Atlantic coast. Environ Sci Pollut Res 20, 723-737.

Caporaso, J.G., Kuczynski, J., Stombaugh, J., Bittinger, K., Bushman, F.D., Costello, E.K., Fierer, N., Pena, A.G., Goodrich, J.K., Gordon, J.I., Huttley, G.A., Kelley, S.T., Knights, D., Koenig, J.E., Ley, R.E., Lozupone, C.A., McDonald, D., Muegge, B.D., Pirrung, M., Reeder, J., Sevinsky, J.R., Turnbaugh, P.J., Walters, W.A., Widmann, J., Yatsunenko, T., Zaneveld, J., Knight, R., 2010. QIIME allows analysis of high-throughput community sequencing data. Nature methods 7, 335-336.

Carmichael, R.H., Jones, A.L., Patterson, H.K., Walton, W.C., Perez-Huerta, A., Overton, E.B., Dailey, M., Willett, K.L., 2012. Assimilation of Oil-Derived Elements by Oysters Due to the Deepwater Horizon Oil Spill. Environmental Science \& Technology 46, 1278712795. 
Clayton, T.A., Baker, D., Lindon, J.C., Everett, J.R., Nicholson, J.K., 2009.

Pharmacometabonomic identification of a significant host-microbiome metabolic interaction affecting human drug metabolism. Proc Natl Acad Sci U S A 106, 1472814733.

Costa, P.M., Diniz, M.S., Caeiro, S., Lobo, J., Martins, M., Ferreira, A.M., Caetano, M., Vale, C., DelValls, T.A., Costa, M.H., 2009. Histological biomarkers in liver and gills of juvenile Solea senegalensis exposed to contaminated estuarine sediments: a weighted indices approach. Aquat Toxicol 92, 202-212.

Crowe, K.M., Newton, J.C., Kaltenboeck, B., Johnson, C., 2014. Oxidative Stress Responses of Gulf Killifish Exposed to Hydrocarbons from the Deepwater Horizon Oil Spill: Potential Implications for Aquatic Food Resources. Environmental Toxicology and Chemistry 33, 370-374.

Dowd, S.E., Callaway, T.R., Wolcott, R.D., Sun, Y., McKeehan, T., Hagevoort, R.G., Edrington, T.S., 2008. Evaluation of the bacterial diversity in the feces of cattle using 16S rDNA bacterial tag-encoded FLX amplicon pyrosequencing (bTEFAP). BMC Microbiology 8.

Dubansky, B., Whitehead, A., Miller, J.T., Rice, C.D., Galvez, F., 2013. Multitissue Molecular, Genomic, and Developmental Effects of the Deepwater Horizon Oil Spill on Resident Gulf Killifish (Fundulus grandis). Environmental Science \& Technology 47, 5074-5082.

Echols, B.S., Smith, A.J., Gardinali, P.R., Rand, G.M., 2015. Acute aquatic toxicity studies of Gulf of Mexico water samples collected following the Deepwater Horizon incident (May 12, 2010 to December 11, 2010). Chemosphere 120, 131-137.

Edgar, R.C., 2010. Search and clustering orders of magnitude faster than BLAST. Bioinformatics 26, 2460-2461.

Edgar, R.C., Haas, B.J., Clemente, J.C., Quince, C., Knight, R., 2011. UCHIME improves sensitivity and speed of chimera detection. Bioinformatics 27, 2194-2200.

Faraggi, D., Izikson, P., Reiser, B., 2003. Confidence intervals for the 50 per cent response dose. Stat Med 22, 1977-1988.

Ferguson, H., 2006. Systemic Pathology of Fish: A Text and Atlas of Normal Tissue Responses in Teleosts, and Their Responses in Disease., 2nd ed. Scotian Press, p. 368.

Floyd, E.L., Lungu, C.T., Gohlke, J.M., 2012. An Evaluation of Nearshore Sediment Data after the Deepwater Horizon Blowout. Journal of Environmental Science and Engineering A 1, 341-350.

Gambardella, C., Gallus, L., Amaroli, A., Terova, G., Masini, M.A., Ferrando, S., 2012. Fasting and re-feeding impact on leptin and aquaglyceroporin 9 in the liver of European sea bass (Dicentrarchus labrax). Aquaculture 354, 1-6.

Goodbody-Gringley, G., Wetzel, D.L., Gillon, D., Pulster, E., Miller, A., Ritchie, K.B., 2013. Toxicity of Deepwater Horizon Source Oil and the Chemical Dispersant, Corexit (R) 9500, to Coral Larvae. Plos One 8.

Greer, C., Hodson, P., Li, Z., King, T., Lee, K., 2012. Toxicity of crude oil chemically dispersed in a wave tank to embryos of Atlantic herring (Clupea harengus). Environmental Toxicology and Chemistry 31, 1324-1333.

Haensly, W.E., Neff, J.M., Sharp, J.R., Morris, A.C., Bedgood, M.F., Boem, P.D., 1982. Histopathology of Pleuronectes platessa L. from Aber Wrac'h and Aber Benoit, Brittany, France: long-term effects of the Amoco Cadiz crude oil spill. Journal of Fish Diseases 5, 365-391. 
Harayama, S., Kasai, Y., Hara, A., 2004. Microbial communities in oil-contaminated seawater. Current Opinion in Biotechnology 15, 205-214.

Hicken, C.E., Linbo, T.L., Baldwin, D.H., Willis, M.L., Myers, M.S., Holland, L., Larsen, M., Stekoll, M.S., Rice, S.D., Collier, T.K., Scholz, N.L., Incardona, J.P., 2011. Sublethal exposure to crude oil during embryonic development alters cardiac morphology and reduces aerobic capacity in adult fish. Proceedings of the National Academy of Sciences of the United States of America 108, 7086-7090.

Hong, S., Khim, J.S., Ryu, J., Kang, S.G., Shim, W.J., Yim, U.H., 2014. Environmental and ecological effects and recoveries after five years of the Hebei Spirit oil spill, Taean, Korea. Ocean Coast Manage 102, 522-532.

Hylland, K., 2006. Polycyclic aromatic hydrocarbon (PAH) ecotoxicology in marine ecosystems. Journal of Toxicology and Environmental Health-Part a-Current Issues 69, 109-123.

Incardona, J.P., Gardner, L.D., Linbo, T.L., Brown, T.L., Esbaugh, A.J., Mager, E.M., Stieglitz, J.D., French, B.L., Labenia, J.S., Laetz, C.A., Tagal, M., Sloan, C.A., Elizur, A., Benetti, D.D., Grosell, M., Block, B.A., Scholz, N.L., 2014. Deepwater Horizon crude oil impacts the developing hearts of large predatory pelagic fish, Proceedings of the National Academy of Sciences.

Kahn, R.A., 1995. Histopathology in winter flounder, Pleuronectes americanus, following chronic exposure to crude oil. Bull. Environ. Contam. Toxicol.

Khan, R.A., 2003. Health of Flatfish from Localities in Placentia Bay, Newfoundland, Contaminated with Petroleum and PCBs. Archives of Environmental Contamination and Toxicology 44, 0485-0492.

Kimbrough, K.L., Lauenstein, G.G., Johnson, W.E., 2006. Organic Contaminant Analytical methods of the National Status and Trends Program: Update 2000-2006., NOAA Technical Memorandum NOS NCCOS 30, pp. 25-37.

Kleinkauf, A., Connor, L., Swarbreck, D., Levene, C., Walker, P., Johnson, P.J., Leah, R.T., 2004. General condition biomarkers in relation to contaminant burden in European flounder (Platichthys flesus). Ecotoxicology and Environmental Safety 58, 335-355.

Langille, M.G.I., Zaneveld, J., Caporaso, J.G., McDonald, D., Knights, D., Reyes, J.A., Clemente, J.C., Burkepile, D.E., Vega Thurber, R.L., Knight, R., Beiko, R.G., Huttenhower, C., 2013. Predictive functional profiling of microbial communities using 16S rRNA marker gene sequences. Nat Biotech 31, 814-821.

Liu, Y.J., Chen, Y.P., Jin, P.K., Wang, X.C., 2009. Bacterial communities in a crude oil gathering and transferring system (China). Anaerobe 15, 214-218.

Liu, Z., Liu, J., 2013. Evaluating bacterial community structures in oil collected from the sea surface and sediment in the northern Gulf of Mexico after the Deepwater Horizon oil spill. Microbiology Open 2, 492-504.

Liu, Z., Liu, J., Zhu, Q., Wu, W., 2012. The weathering of oil after the Deepwater Horizon oil spill: insights from the chemical composition of the oil from the sea surface, salt marshes and sediments. Environmental Research Letters 7, 14 pp.

Love, M.I., Huber, W., Anders, S., 2014. Moderated estimation of fold change and dispersion for RNA-Seq data with DESeq2.

Manning, C.S., Schesny, A.L., Hawkins, W.E., Barnes, D.H., Barnes, C.S., Walker, W.W., 1999. Exposure methodologies and systems for long-term chemical carcinogenicity studies with small fish species. Toxicology Methods 9, 201-217. 
McCall, B.D., Pennings, S.C., 2012. Disturbance and Recovery of Salt Marsh Arthropod Communities following BP Deepwater Horizon Oil Spill. Plos One 7.

McDonald, D., Price, M.N., Goodrich, J., Nawrocki, E.P., DeSantis, T.Z., Probst, A., Andersen, G.L., Knight, R., Hugenholtz, P., 2012. An improved Greengenes taxonomy with explicit ranks for ecological and evolutionary analyses of bacteria and archaea. ISME J 6, 610618.

Michel, J., Owens, E.H., Zengel, S., Graham, A., Nixon, Z., Allard, T., Holton, W., Reimer, P.D., Lamarche, A., White, M., Rutherford, N., Childs, C., Mauseth, G., Challenger, G., Taylor, E., 2013. Extent and Degree of Shoreline Oiling: Deepwater Horizon Oil Spill, Gulf of Mexico, USA. Plos One 8.

Moles, A., Norcross, B.L., 1998. Effects of oil-laden sediments on growth and health of juvenile flatfishes. Canadian Journal of Fisheries and Aquatic Sciences 55, 605-610.

Murphy, B.L., Morrison, R.D., 2007. Introduction to Environmental Forensics, 2 ed, pp. 389402.

Myers, M.S., Johnson, L.L., Collier, T.K., 2003. Establishing the causal relationship between polycyclic aromatic hydrocarbon (PAH) exposure and hepatic neoplasms and neoplasiarelated liver lesions in English sole (Pleuronectes vetulus). Human and Ecological Risk Assessment 9, 67-94.

Oehlers, S.H., Flores, M.V., Okuda, K.S., Hall, C.J., Crosier, K.E., Crosier, P.S., 2011. A chemical enterocolitis model in zebrafish larvae that is dependent on microbiota and responsive to pharmacological agents. Developmental Dynamics 240, 288-298.

Ortmann, A.C., Anders, J., Shelton, N., Gong, L.M., Moss, A.G., Condon, R.H., 2012. Dispersed Oil Disrupts Microbial Pathways in Pelagic Food Webs. Plos One 7.

Peterson, C.H., Rice, S.D., Short, J.W., Esler, D., Bodkin, J.L., Ballachey, B.E., Irons, D.B., 2003. Long-term ecosystem response to the Exxon Valdez oil spill. Science 302, 20822086.

Pilcher, W., Miles, S., Tang, S., Mayer, G., Whitehead, A., 2014. Genomic and genotoxic responses to controlled weathered-oil exposures confirm and extend field studies on impacts of the deepwater horizon oil spill on native killifish. PLoS One 9, e106351.

R Core Team, 2013. R: A Language and Environment for Statistical Computing. , 3.1.1 "Spring Dance" ed. R Foundation for Statistical Computing, Vienna, Austria.

R Development Core Team, 2013. The R Project for Statistical Computing. R Foundation for Statistical Computing, Vienna, Austria.

Raimondo, S., Jackson, C.R., Krzykwa, J., Hemmer, B.L., Awkerman, J.A., Barron, M.G., 2014. Developmental toxicity of Louisiana crude oil-spiked sediment to zebrafish. Ecotoxicol Environ Saf 108, 265-272.

Ritz, C., 2010. Toward a unified approach to dose-response modeling in ecotoxicology. Environ Toxicol Chem 29, 220-229.

Ritz, C., Streibig, J.C., 2005. Bioassay analysis using R. J Stat Softw 12, 1-22.

Roy, L.A., Steinert, S., Bay, S.M., Greenstein, D., Sapozhnikova, Y., Bawardi, O., Leifer, I., Schlenk, D., 2003. Biochemical effects of petroleum exposure in hornyhead turbot (Pleuronichthys verticalis) exposed to a gradient of sediments collected from a natural petroleum seep in CA, USA. Aquat Toxicol 65, 159-169.

Rozas, L.P., Minello, T.J., Miles, M.S., 2014. Effect of Deepwater Horizon Oil on Growth Rates of Juvenile Penaeid Shrimps. Estuar Coast 37, 1403-1414. 
Sabirova, J.S., Ferrer, M., Regenhardt, D., Timmis, K.N., Golyshin, P.N., 2006. Proteomic insights into metabolic adaptations in Alcanivorax borkumensis induced by alkane utilization. Journal of Bacteriology 188, 3763-3773.

Sarasquete, C., Segner, H., 2000. Cytochrome P4501A (CYP1A) in teleostean fishes. A review of immunohistochemical studies. Sci Total Environ 247, 313-332.

Schneiker, S., dos Santos, V.A.P.M., Bartels, D., Bekel, T., Brecht, M., Buhrmester, J., Chernikova, T.N., Denaro, R., Ferrer, M., Gertler, C., Goesmann, A., Golyshina, O.V., Kaminski, F., Khachane, A.N., Lang, S., Linke, B., McHardy, A.C., Meyer, F., Nechitaylo, T., Puhler, A., Regenhardt, D., Rupp, O., Sabirova, J.S., Selbitschka, W., Yakimov, M.M., Timmis, K.N., Vorholter, F.J., Weidner, S., Kaiser, O., Golyshin, P.N., 2006. Genome sequence of the ubiquitous hydrocarbon-degrading marine bacterium Alcanivorax borkumensis. Nature Biotechnology 24, 997-1004.

Schwacke, L.H., Smith, C.R., Townsend, F.I., Wells, R.S., Hart, L.B., Balmer, B.C., Collier, T.K., De Guise, S., Fry, M.M., Guillette, L.J., Lamb, S.V., Lane, S.M., McFee, W.E., Place, N.J., Tumlin, M.C., Ylitalo, G.M., Zolman, E.S., Rowles, T.K., 2013. Health of Common Bottlenose Dolphins (Tursiops truncatus) in Barataria Bay, Louisiana, Following the Deepwater Horizon Oil Spill. Environmental Science \& Technology.

Silliman, B.R., van de Koppel, J., McCoy, M.W., Diller, J., Kasozi, G.N., Earl, K., Adams, P.N., Zimmerman, A.R., 2012. Degradation and resilience in Louisiana salt marshes after the BP-Deepwater Horizon oil spill. Proceedings of the National Academy of Sciences of the United States of America 109, 11234-11239.

Tan, T., Wang, B., Shao, Z., 2009. Donghicola xiamenensis sp. nov., a marine bacterium isolated from seawater of the Taiwan Strait in China. International Journal of Systematic and Evolutionary Microbiology 59, 1143-1147.

Tomkiewicz, J., Kofoed, T.M.N., Pedersen, J.S., 2011. Assessment of Testis Development during Induced Spermatogenesis in the European Eel Anguilla anguilla. Marine and Coastal Fisheries 3, 106-118.

Turner, R.E., Overton, E.B., Meyer, B.M., Miles, M.S., Hooper-Bui, L., 2014. Changes in the concentration and relative abundance of alkanes and PAHs from the Deepwater Horizon oiling of coastal marshes. Mar Pollut Bull 86, 291-297.

Venzon, D.J., Moolgavkar, S.H., 1988. A Method for Computing Profile-Likelihood-Based Confidence Intervals. Journal of the Royal Statistical Society. Series C (Applied Statistics) 37, 87-94.

Wang, P., Roberts, T.M., 2013. Distribution of Surficial and Buried Oil Contaminants across Sandy Beaches along NW Florida and Alabama Coasts Following the Deepwater Horizon Oil Spill in 2010. Journal of Coastal Research 29, 144-155.

Wang, Q., Garrity, G.M., Tiedje, J.M., Cole, J.R., 2007. Naive Bayesian classifier for rapid assignment of rRNA sequences into the new bacterial taxonomy. Applied and environmental microbiology 73, 5261-5267.

Whitehead, A., Dubansky, B., Bodinier, C., Garcia, T.I., Miles, S., Pilley, C., Raghunathan, V., Roach, J.L., Walker, N., Walter, R.B., 2011. Genomic and physiological footprint of the Deepwater Horizon oil spill on resident marsh fishes. Proceedings of the National Academy of Sciences 109, 20298-20302.

Wise, J.P.J., J. T. F. Wise, C. F. Wise, S. S. Wise, C. Gianios, Jr., H. Xie., W. D. Thompson, C. Perkins, C. Falank, and J. P. Wise, S., 2014. Concentrations of the Genotoxic Metals, Chromium and Nickel, in Whales, Tar Balls, Oil Slicks, and Released 
Oil from the Gulf of Mexico in the Immediate Aftermath of the Deepwater Horizon Oil Crisis: Is Genotoxic Metal Exposure Part of the Deepwater Horizon Legacy?

Environmental Science \& Technology, DOI:10.1021/es405079b.

Wolf, J.C., Baumgartner, W.A., Blazer, V.S., Camus, A.C., Engelhardt, J.A., Fournie, J.W., Frasca, S., Jr., Groman, D.B., Kent, M.L., Khoo, L.H., Law, J.M., Lombardini, E.D., Ruehl-Fehlert, C., Segner, H.E., Smith, S.A., Spitsbergen, J.M., Weber, K., Wolfe, M.J., 2014a. Nonlesions, Misdiagnoses, Missed Diagnoses, and Other Interpretive Challenges in Fish Histopathology Studies: A Guide for Investigators, Authors, Reviewers, and Readers. Toxicologic pathology.

Wolf, J.C., Ruehl-Fehlert, C., Segner, H.E., Weber, K., Hardisty, J.F., 2014b. Pathology working group review of histopathologic specimens from three laboratory studies of diclofenac in trout. Aquatic Toxicology 146, 127-136.

Wolf, J.C., Wolfe, M.J., 2005. A brief overview of nonneoplastic hepatic toxicity in fish. Toxicologic pathology 33, 75-85.

Zachary, J., McGavin, M., 2012. Pathologic Basis of Veterinary Disease. Elsevier, St. Louis, MO. 


\section{Supplemental Figures and Tables.}

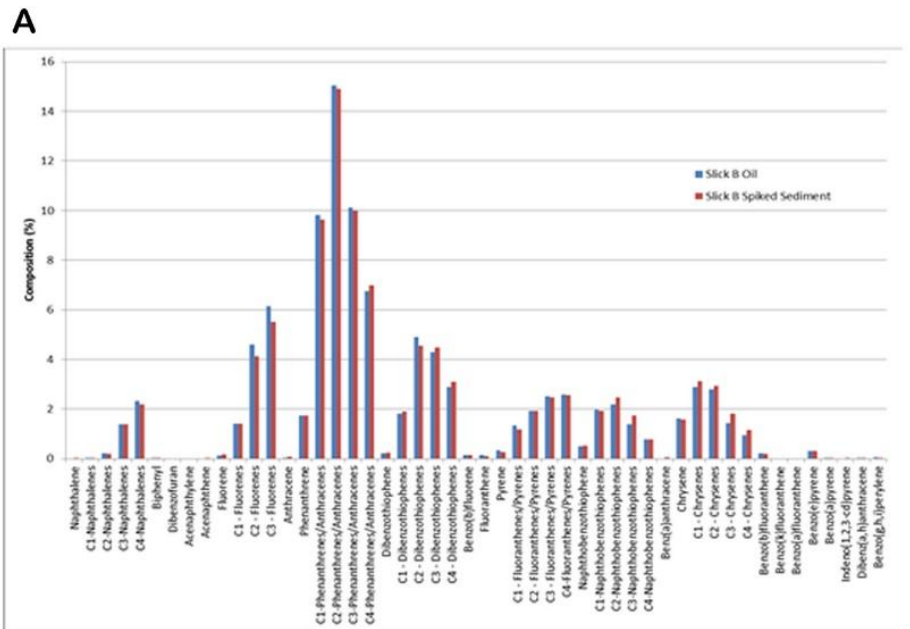

B
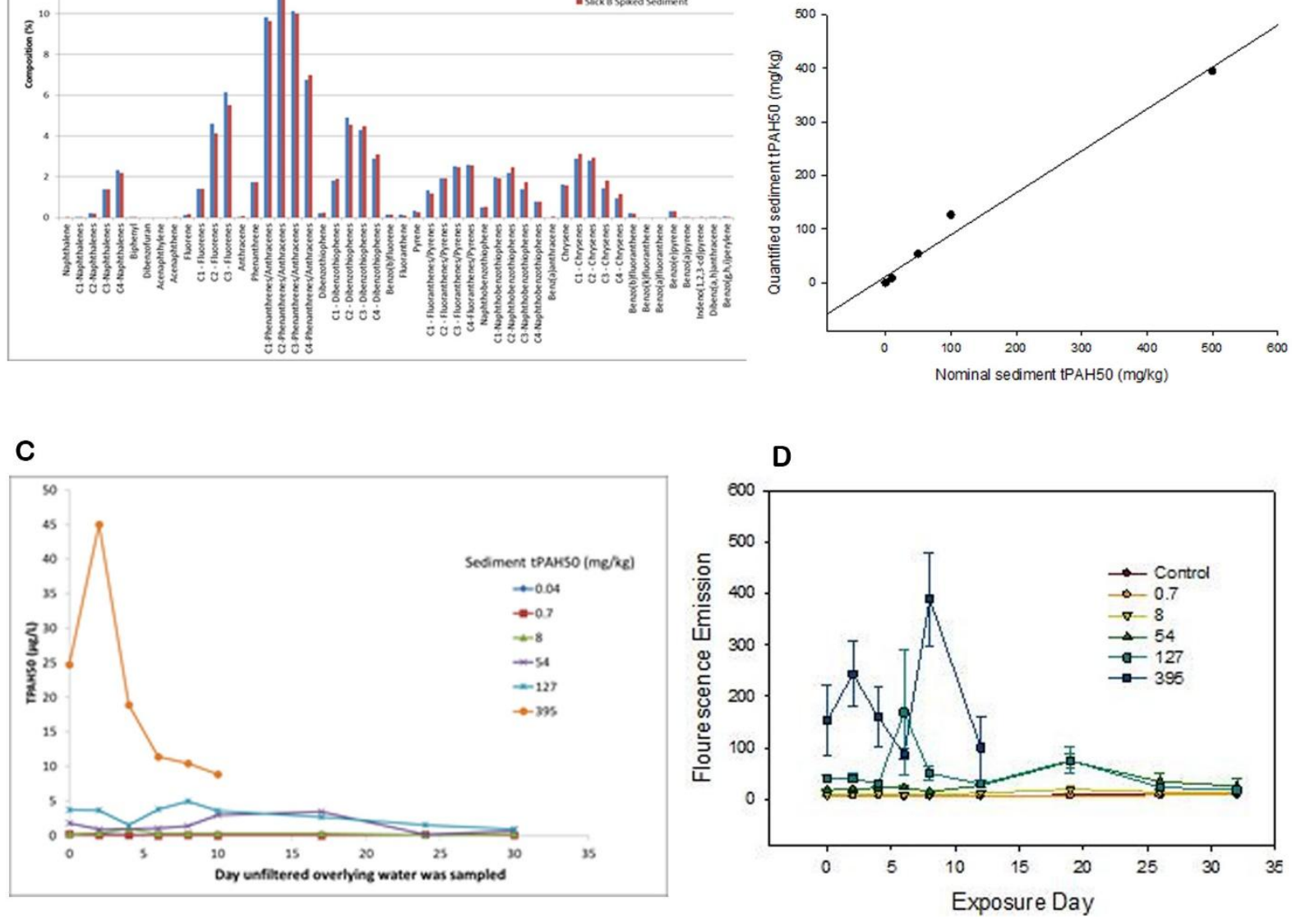

Figure S1. Quantification of oiled sediments and overlying water. A. Composition of 50 measured PAH analytes in Slick B weathered oil and uncontaminated sediment spiked with Slick B weathered oil. B. Relationship between the amount of Slick B oil added to sediments (nominal sediment tPAH50) and quantified concentration C. Concentration $(\mu \mathrm{g} / \mathrm{L})$ of tPAH50 in unfiltered water overlying oil-spiked sediments during the 32-day study. Values represent a composite of replicate aquaria for each treatment. Water samples not collected from the $395 \mathrm{mg} / \mathrm{kg}$ sediment treatment after day 11 due to $100 \%$ mortality in that treatment. D. Mean $( \pm$ SE) fluorescence values of unfiltered water overlying sediments demonstrating variability among replicate aquaria. 


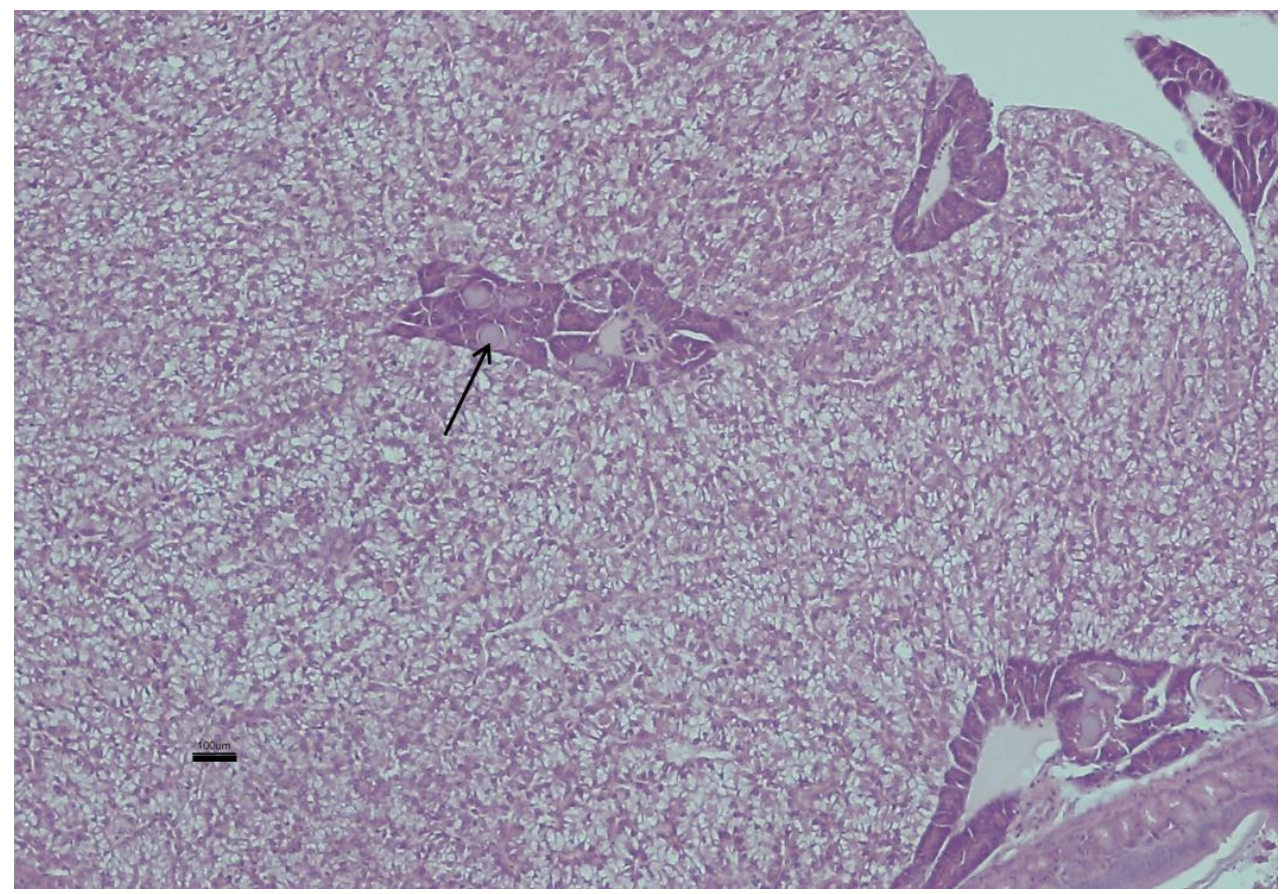

Figure S2. Histological section of liver tissue from flounder exposed to oiled sediment (127 $\mathrm{mg} / \mathrm{kg}$ tPAH50). Bar $=100 \mu \mathrm{m}$. Arrow indicates large eosinophilic inclusions in the duct lumens/cells. 

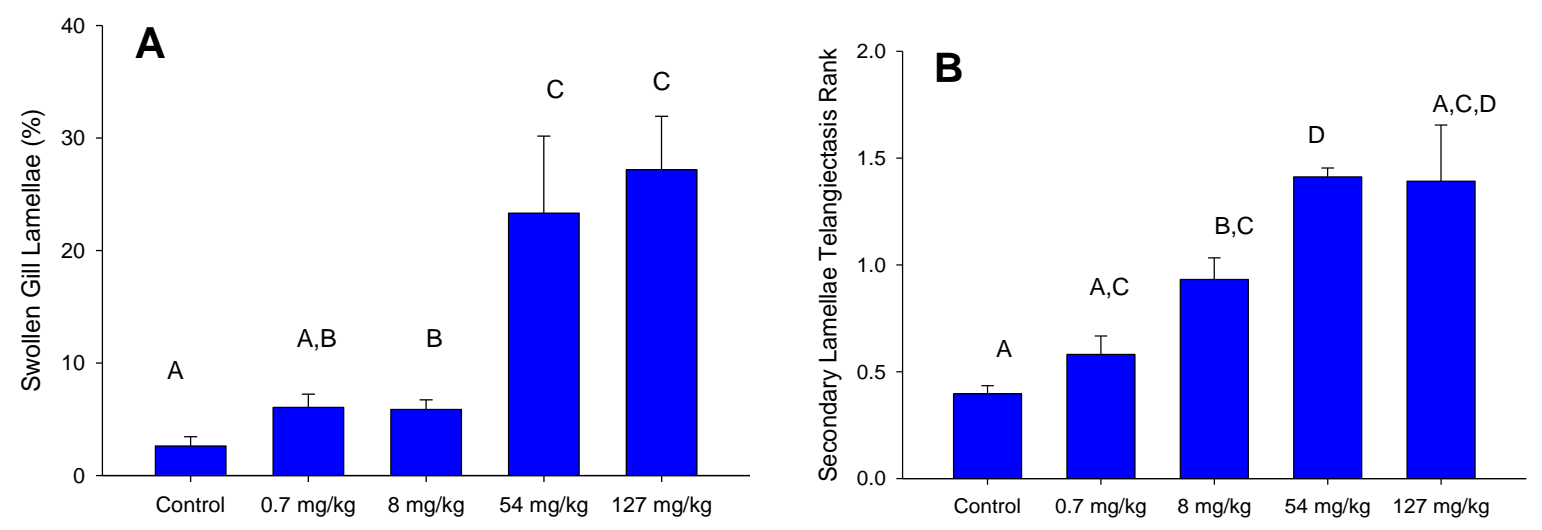

Figure S3. Histopathologic effects on southern flounder gill tissue after 32 days of exposure to oiled sediment. A. Mean ( \pm S.E.) percentage of fused gill lamellae observed in five oiled sediment treatments. B. Rank values of secondary lamellae exhibiting telangiectasis in five oiled sediment treatments. Letters indicate significant differences among treatments (ANOVA, Bonferroni post-hoc test). 
Table S1. Amount of sediment, loading rate of Slick B oil, and initial and final concentrations of treatments. Initial measurements taken at experiment initiation, final measurements taken after 32-d of flow-through clean water at experiment termination.

\begin{tabular}{|l|l|l|l|l|}
\hline Treatment & $\begin{array}{l}\text { Sediment Mass } \\
(\mathrm{kg})\end{array}$ & $\begin{array}{l}\text { Nominal } \\
\text { loading } \\
\text { concentration } \\
(\mathrm{g} / \mathrm{kg})\end{array}$ & $\begin{array}{l}\text { Measured } \\
\text { concentration at } \\
\text { initiation }(\mathrm{mg} / \mathrm{kg} \\
\text { tPAH50) }\end{array}$ & $\begin{array}{l}\text { Measured concentration } \\
\text { at termination }(\mathrm{mg} / \mathrm{kg} \\
\text { tPAH50) }\end{array}$ \\
\hline 1 & 3.207 & 0 & 0.031 & 0.023 \\
\hline 2 & 3.221 & 0.499 & 0.656 & 0.573 \\
\hline 3 & 3.702 & 4.51 & 8.4 & 6.36 \\
\hline 4 & 3.216 & 25.1 & 53.9 & 50.09 \\
\hline 5 & 3.202 & 56.2 & 126.6 & 188.7 \\
\hline 6 & 3.204 & 270.2 & 394.9 & 425.2 \\
\hline
\end{tabular}

Table S2. Grain size characteristics of the sediment used in this experiment. Grain size was analyzed from a composite sample taken from the field-collected sediment prior to spiking with oil, and therefore is representative of all treatments.

\begin{tabular}{|l|l|l|}
\hline Grain Type & Grain Size $(\mathrm{mm})$ & Composition $(\%)$ \\
\hline Gravel & $>2.00$ & 0.04 \\
\hline Sand, very coarse & $1.00-2.00$ & 0.06 \\
\hline Sand, coarse & $0.50-1.00$ & 0.25 \\
\hline Sand, medium & $0.250-0.0500$ & 10.29 \\
\hline Sand, fine & $0.125-0.250$ & 44.51 \\
\hline Sand, very fine & $0.0625-0.125$ & 15.04 \\
\hline Silt & $0.0039-0.0625$ & 19.63 \\
\hline Clay & $<0.0039$ & 6.97 \\
\hline
\end{tabular}


Table S3. Summary of consensus opinion of histological observations on four tissues of juvenile southern flounder exposed to oiled sediments for 32 days. Score is ranked as 0 (condition not present) and 1 (condition present). N indicates total number of specimens containing each tissue type on the slide; score numbers indicate total number of specimens with that score for each histological observation at each treatment concentration. Values in parentheses indicate the percentage of fish exhibiting each condition per treatment.

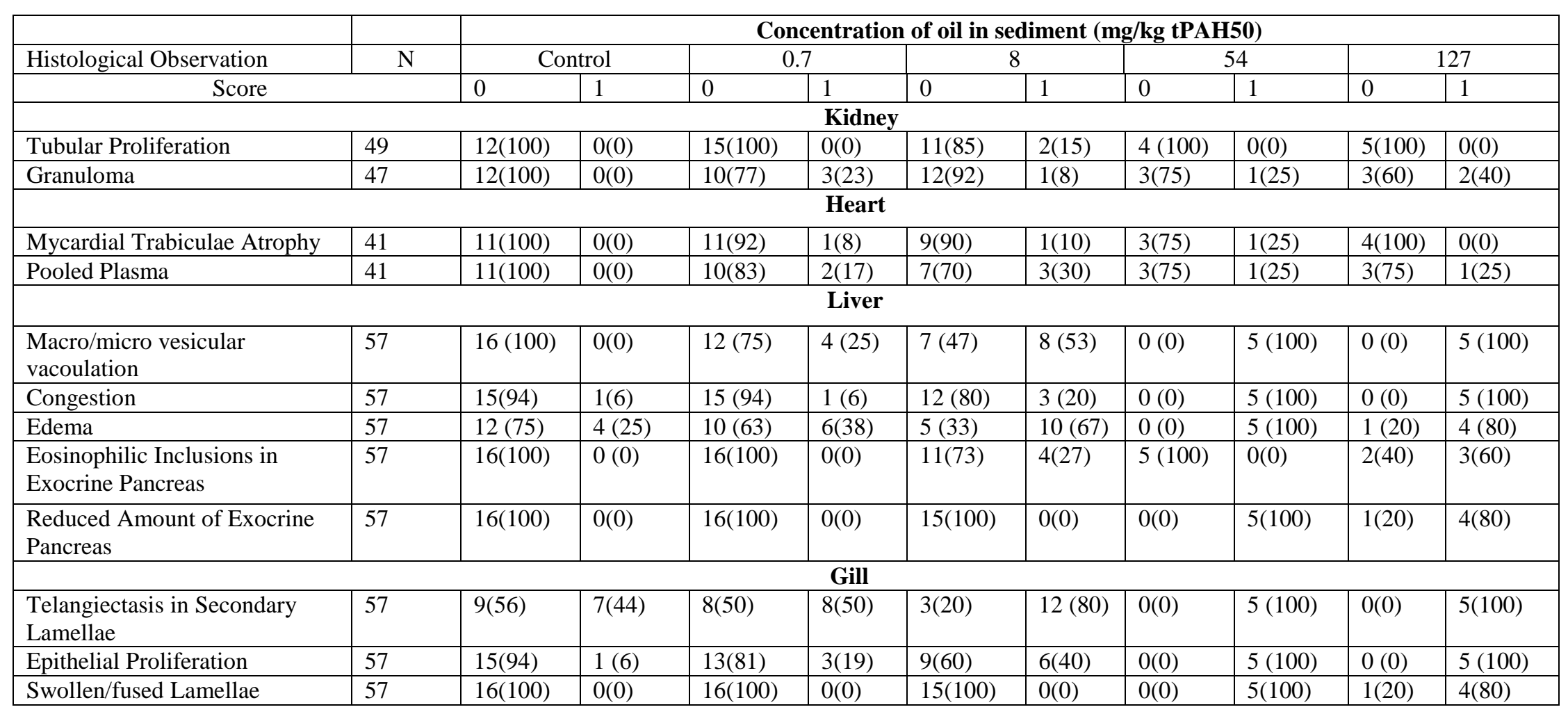


Table S4. Presence of food in stomachs and intestines of juvenile southern flounder exposed to oiled sediments for 32 days. Data expressed as percentage of total number of flounder in each treatment

\begin{tabular}{|l|l|l|l|l|l|l|}
\hline \multirow{2}{*}{$\begin{array}{l}\text { Treatment } \\
(\mathrm{mg} / \mathrm{kg} \text { tPAH50) }\end{array}$} & $\mathrm{N}$ & \multicolumn{3}{|c|}{ Stomach } & \multicolumn{2}{c|}{ Intestine } \\
\cline { 2 - 7 } & & Full & Part full & Empty & Food present & Empty \\
\hline Control & 16 & 100 & 0 & 0 & 100 & 0 \\
\hline 0.7 & 15 & 100 & 0 & 0 & 100 & 0 \\
\hline 8 & 15 & 93 & 0 & 7 & 100 & 0 \\
\hline 54 & 5 & 0 & 20 & 80 & 0 & 100 \\
\hline 127 & 5 & 60 & 0 & 40 & 20 & 80 \\
\hline
\end{tabular}

